\title{
A swelling pressure cell for X-ray diffraction test
}

\author{
HAILONG WANG*, HIDEO KOMINE $\uparrow$ and TAKAHIRO GOTOH $\$$
}

\begin{abstract}
A swelling pressure cell is introduced to measure apparent swelling pressure $\left(p_{\mathrm{s}}\right)$ and basal spacing of montmorillonite $\left(d_{001}\right)$ simultaneously for compacted bentonite during water absorption. Specimens with an initial dry density of up to $1.7 \mathrm{Mg} / \mathrm{m}^{3}$ were prepared with initially oven-dried bentonite powder. Results show that the $p_{\mathrm{s}}$ time history curve has four stages: a sharp increase to the peak swelling pressure $\left(p_{\mathrm{p}}\right)$; a drop to a valley swelling pressure $\left(p_{\mathrm{v}}\right)$; another increase to the initial swelling pressure for equilibrium $\left(p_{\mathrm{ei}}\right)$; and equilibrium swelling pressure $\left(p_{\mathrm{eq}}\right)$. Meanwhile, $d_{001}$ changes from $0.98 \mathrm{~nm}$ to $1.26 \mathrm{~nm}, 1.58 \mathrm{~nm}, 1.90 \mathrm{~nm}$ and $4.0 \mathrm{~nm}$ gradually during water absorption. Results imply that crystalline swelling of montmorillonite serves an important role for interpretation of $p_{\mathrm{s}}$ behaviour of tested specimens. Another testing programme to measure $p_{\mathrm{s}}$ compacted bentonite only was conducted using the swelling pressure cell. Results suggest that specimen dry density closely correlates with feature points of $p_{\mathrm{s}}$ time history (i.e. $p_{\mathrm{p}}, p_{\mathrm{v}}, p_{\mathrm{ei}}$ and $p_{\mathrm{eq}}$ ), which is consistent with results of earlier studies. Importantly, the $2 \mathrm{~mm}$ specimen thickness was used, which reduced the test duration to less than $24 \mathrm{~h}$. Evidence from experiments suggests that the swelling pressure cell is a powerful and inexpensive tool for studying the swelling behaviour of compacted bentonite.
\end{abstract}

KEYWORDS: clays; expansive soils; geology; laboratory tests; mineralogy; radioactive waste disposal

\section{INTRODUCTION}

Multi-barrier systems in geological disposal projects are being considered in many countries as a solution to dispose of high-level radioactive waste or spent nuclear fuel (e.g. JNC, 1999; SKB, 2011; Posiva, 2012; METI, 2018). Bentonite, a montmorillonite-rich clay, is widely selected as a candidate material for buffer and backfill materials of the multi-barrier system in Japan because of its low permeability, swelling properties and so on (JNC, 1999). As a parameter for system design, the pressure generated during water absorption of compacted bentonite under the swelling deformation confined condition has been studied extensively (e.g. Pusch, 1980; Sridharan et al., 1986; Komine, 2004; Villar \& Lloret, 2008; Tanai et al., 2010; Wang et al., 2012). Herein, the present authors designate the pressure measured for deformationconfined bentonite as apparent swelling pressure $\left(p_{\mathrm{s}}\right)$ with the consideration that $p_{\mathrm{s}}$ represents a combination of forces between montmorillonite layers (Warkentin, 1962; Viani et al., 1983) and interactions between montmorillonite particles and non-swelling particles in bentonite. Swelling of montmorillonite has long been known to be the result of water molecule penetration into the interlayer space of montmorillonite and associated basal spacing $\left(d_{001}\right)$ increase of the sheeted tetrahedral-octahedral-tetrahedral structure (Foster et al., 1954; Norrish, 1954; Fink et al., 1968; Moore \& Hower, 1986; Iwasaki \& Watanabe, 1988; Watanabe \& Sato, 1988; Olis et al., 1990; Sato et al., 1992; Yamada et al., 1994; Moore \& Reynolds, 1997; Morodome \& Kawamura, 2009,

Manuscript received 31 August 2020; revised manuscript accepted 26 January 2021. Published online ahead of print 3 March 2021.

Discussion on this paper closes on 1 December 2022, for further details see p. ii.

Published with permission by the ICE under the CC-BY 4.0 license. (http://creativecommons.org/licenses/by/4.0/)

* Global Center for Science and Engineering, Waseda University, Tokyo, Japan (Orcid:0000-0001-8814-6351).

$\dagger$ Department of Civil and Environmental Engineering, Waseda University, Tokyo, Japan.

t Materials Characterization Central Laboratory, Waseda University, Tokyo, Japan.
Wang et al., 2020a, 2020b). As shown in Fig. 1(a), swelling of montmorillonite can be classified as osmotic swelling or crystalline swelling. Osmotic swelling relates to diffusions of water molecules due to a concentration difference of exchangeable cations. It has been said (Norrish, 1954; Meleshyn \& Bunnenberg, 2005), on the one hand, that osmotic swelling starts from $d_{001}=\sim 4.0 \mathrm{~nm}$ and $d_{001}$ linearly increases with an increase in water content $(w)$. On the other hand, crystalline swelling relates to the hydration of different types of exchangeable cations in the interlayer space and $d_{001}$ increases stepwise, usually up to $1.9 \mathrm{~nm}$, with an increase in $w$. As illustrated in Fig. 1(b), each step corresponds to a certain arrangement of water molecule $(L)$ from zero layer $(0 \mathrm{w})$ to three layers $(3 \mathrm{w})$. For both swelling cases, attempts were made to correlate the force between montmorillonite layers with $d_{001}$ using either experimental or theoretical approaches (Warkentin, 1962; Viani et al., 1983; Afzal et al., 1984; Lubetkin et al., 1984; Israelachvili, 2011). However, $p_{\mathrm{s}}$ estimation for compacted bentonite with consideration of $d_{001}$ (or force between montmorillonite layers) behaviours and interactions between montmorillonite particles and non-swelling particles seems to be difficult. Most studies have specifically emphasised $p_{\mathrm{s}}$ at an equilibrium state (e.g. Pusch et al., 1990; Komine, 2004; Kyokawa et al., 2020).

With the objective of providing a useful tool to correlate $d_{001}$ with $p_{\mathrm{s}}$, this paper presents a swelling pressure cell working on X-ray diffractometers, by which $p_{\mathrm{s}}$ and $d_{001}$ are visible simultaneously. A few similar devices have been developed. Warr \& Berger (2007) simultaneously observed $d_{001}$ and water absorption of bentonite specimens with initial dry density up to $1 \cdot 15 \mathrm{Mg} / \mathrm{m}^{3}$, although $p_{\mathrm{s}}$ was not measured. Takahashi et al. (2015) measured $p_{\mathrm{s}}$ and $d_{001}$ simultaneously for bentonite specimens with initial dry density up to $1.88 \mathrm{Mg} / \mathrm{m}^{3}$, but $p_{\mathrm{s}}$ measurement apparently did not fully match the results of observations conducted by other studies. Moreover, about a month was necessary for each test with the device reported by Takahashi et al. (2015). With the cell introduced in this study, both $p_{\mathrm{s}}$ time histories and $d_{001}$ evolution during water absorption of a compacted bentonite were well observed. The test duration was less than 1 day. The initial dry densities of prepared specimens in the testing 


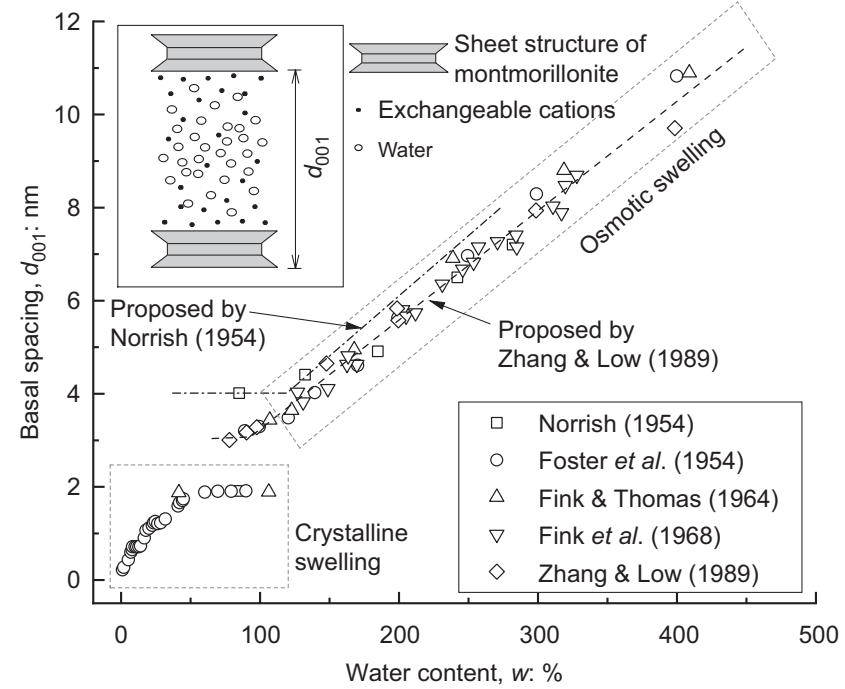

(a)

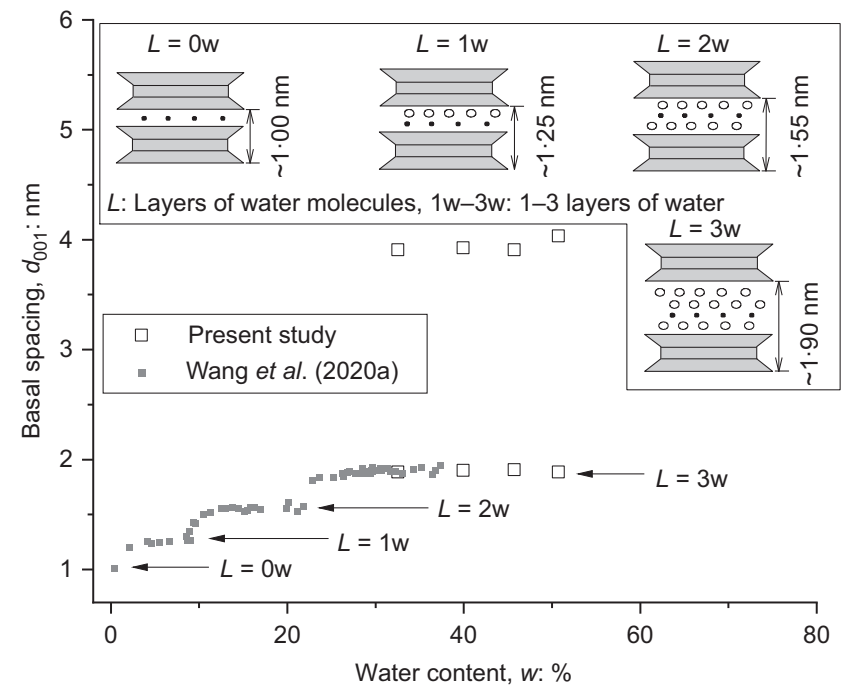

(b)

Fig. 1. Typical experimental results of crystalline and osmotic swelling of montmorillonite (a) for pure montmorillonites, (b) for a bentonite Kunigel V1 (K_V1)

programme were up to $1.7 \mathrm{Mg} / \mathrm{m}^{3}$, a comparable value to that of design in the geological disposal project (JNC, 1999). Another test programme was also conducted to measure $p_{\mathrm{s}}$ only by the cell, for which the testing duration for each specimen was also less than 1 day and similar results to those from past studies were obtained.

\section{TESTING MATERIALS, APPARATUS AND PROGRAMMES \\ Test material}

Commercial bentonite Kunigel V1 (K_V1), which is a sodium ( $\mathrm{Na}$-type bentonite powder and a candidate material for use in Japanese geological disposal projects, was used for all tests conducted for this study. The montmorillonite content was about $50 \%$. The initial water content $\left(w_{\mathrm{i}}\right)$ in the laboratory environment (relative humidity $=\sim 50 \%$, temperature $=23^{\circ} \mathrm{C}$ ) is about $7-9 \%$. Other details are provided in an earlier report (Wang et al., 2020a). Obtaining a very precise value for specific gravity $\left(G_{\mathrm{s}}\right)$ of $\mathrm{K} \_\mathrm{V} 1$ seems not to be easy. A test programme was conducted to measure $G_{\mathrm{s}}$ using the pycnometer method based on JGS (2009), with about 50 samples divided into seven groups (tests in the same group were conducted in the same period). The sample mass for each test was reduced to $1 \cdot 8-6 \mathrm{~g}$, which is $\sim 10$ g recommended by JGS (2009) for clayey soils with the $100 \mathrm{ml}$ pycnometer. This is necessary because the pore air could not be removed easily from $\mathrm{K}$ _V1 during tests for a mass greater than $6 \mathrm{~g}$. To remove pore air, samples were first immersed in about $70-80 \mathrm{ml}$ distilled water in pycnometers. Then negative pressure of $\sim 100 \mathrm{kPa}$ was applied for several days. A balance with resolution of $0.1 \mathrm{mg}$ was used for mass measurements in most tests. It was found that water absorption during cooling of the oven-dried samples in the dissector might cause significant $G_{\mathrm{s}}$ value variation. So sample containers were sealed with rubber plugs during cooling for samples in groups 2-5. Results are presented in Fig. 2, where the group number and period for negative pressure application are indicated in the key. Although many efforts and much care were devoted to this test programme, $G_{\mathrm{s}}$ values are widely scattered. It seems that $G_{\mathrm{s}}$ becomes larger for sample masses less than $2.5 \mathrm{~g}$, which might be partially affected by the mass measurement error and mass loss during tests. Negative pressure applications for one day (group 7) seem to be

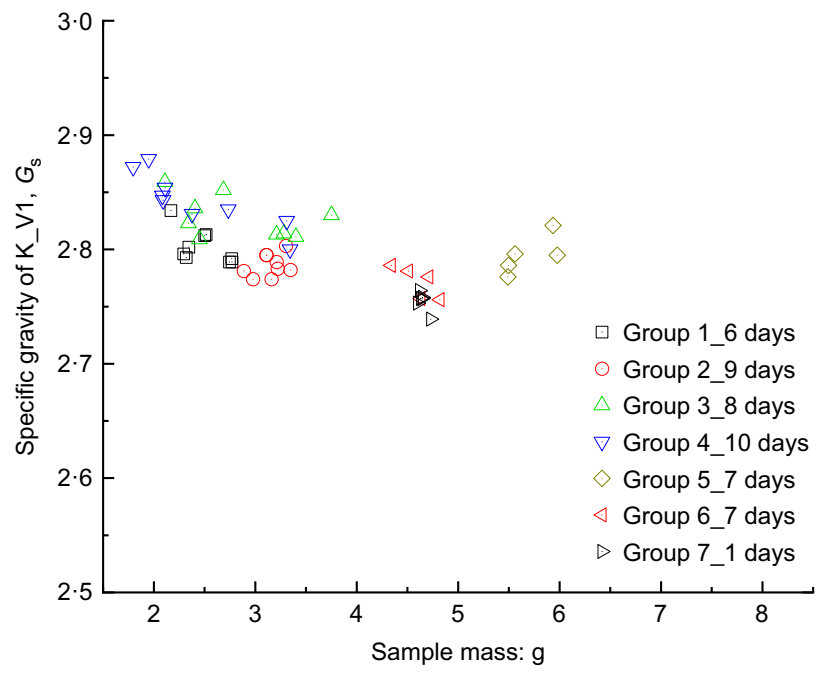

Fig. 2. Results of specific gravity of $K_{-}$V1

insufficient for removing pore air, although the data variation is less than those in other groups. Additionally, detailed test procedures for samples in the same group were kept almost identical, by which variation in each group implies that material heterogeneity might naturally exist. Nevertheless, $G_{\mathrm{s}}=2 \cdot 8$ was adopted in this study.

\section{Swelling pressure cell}

The fundamental idea of powder X-ray diffraction (XRD) for clay is that XRD occurs at a specific incident angle $\left(\theta_{\mathrm{pk}}\right)$ when parallel X-ray beams scan the specimen, as illustrated schematically in Fig. 3(a). This angle reflects the molecular structure of phyllosilicates. By collecting diffracted signals at different angles $(2 \theta)$, a diffraction peak become visible at $\theta_{\mathrm{pk}}$. The value of $d_{001}$ is calculable using Bragg's law as $d_{001}=\lambda / 2 \sin \theta_{\mathrm{pk}}$, where $\lambda$ represents the wavelength of the incident wave $(=0 \cdot 15418 \mathrm{~nm}$ for $\mathrm{Cu} \mathrm{K} \alpha)$. Figures 3(b) and $3(\mathrm{c})$ depict the swelling pressure cell placed on an X-ray diffractometer stage; Figs 3(d) and 3(e), respectively, depict a plan view and cross-section view of the cell. To achieve $\mathrm{X}$-ray scanning while measuring $p_{\mathrm{s}}$, the cell includes three 


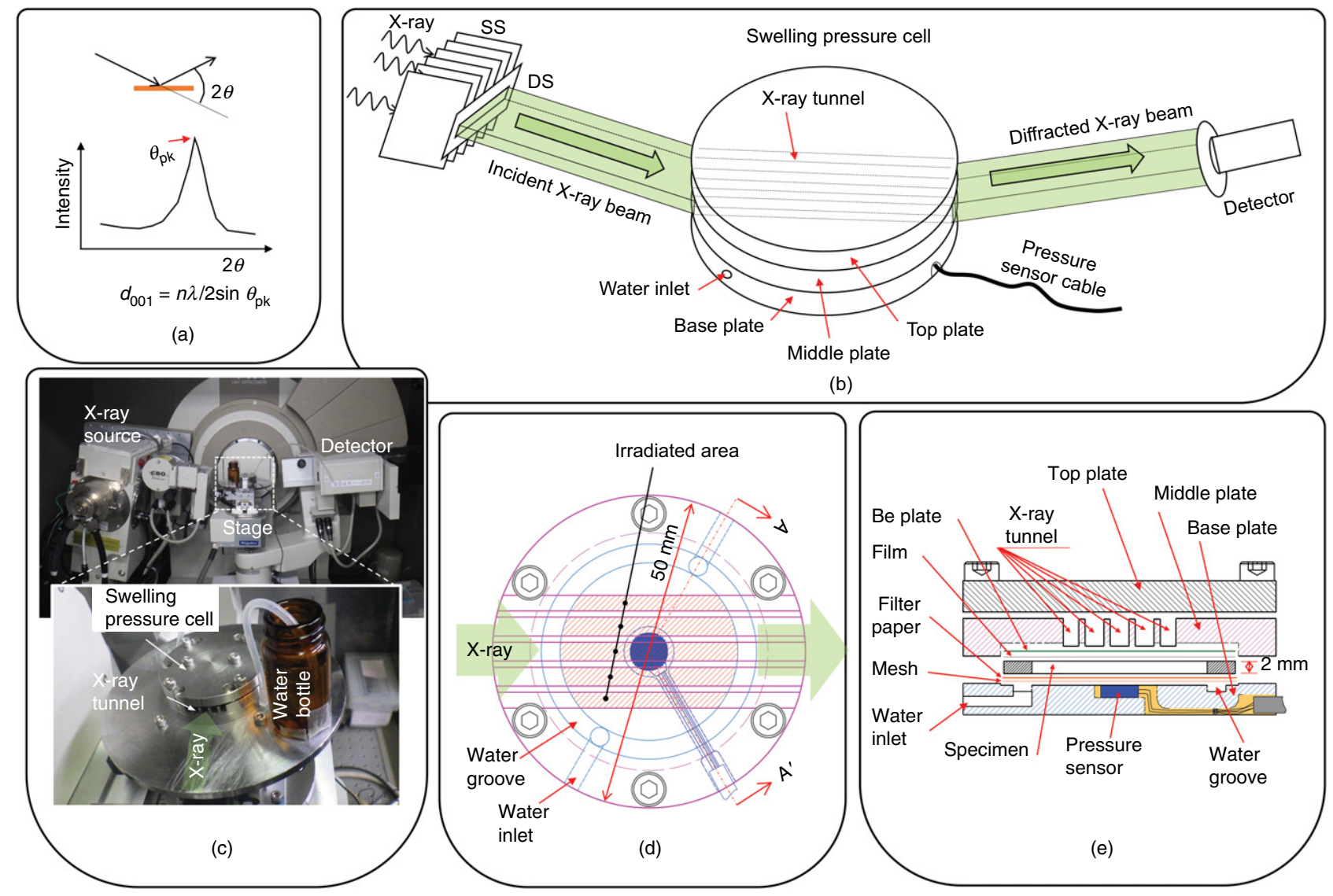

Fig. 3. Illustration of the swelling pressure cell: (a) XRD principle; (b) layout of swelling pressure cell; (c) XRD and swelling pressure cell arrangement; (d) plan view; (e) section $\mathbf{A}-\mathbf{A}^{\prime}$

main components: a base plate, a middle plate and a top plate. A pressure sensor with diameter $(\phi)$ of $6 \mathrm{~mm}$ was installed at the centre of the base plate. A filter paper and a stainless mesh, as media to transport water to the specimen from water groove, were placed between the specimen and the base plate. Two water inlets connected to a cylindrical water groove were designed: one connected to the water supply bottle; the other connected to a tube for water level observation in the water bottle. The specimen with $\phi$ of $28 \mathrm{~mm}$ and thickness $(t)$ of $2 \mathrm{~mm}$ was confined in a stainless specimen ring. This specimen ring was fixed to the middle plate, where a polyester film $(t=6 \mu \mathrm{m})$ and a beryllium $(\mathrm{Be})$ plate $(t=0.1 \mathrm{~mm})$ were placed above the specimen. Be plates are often used as X-ray windows because of their high X-ray transmission and mechanical strength. The present authors found that the Be plate can be eroded by wetted bentonite; therefore, the polyester film was further added. For the middle plate, several X-ray tunnels (i.e. slits) were reserved. The tunnel height was about $4 \mathrm{~mm}$, which ensures X-ray passage from $2 \theta=0-19^{\circ}$. Apparently, confinement is weaker at the tunnelling area, so the top plate was added to reduce the specimen deformation. Note that water is not sealed for this cell, while no apparent leakage was observed if the water level in the water bottle was not higher than the middle plate surface.

Figure 3 is the latest version of the cell; yet some technical issues found during the development of the cell are worth presenting. The initial version of the middle plate had only one wide tunnel for the passage of X-rays, as presented in Fig. 4. With this plate, some tests were conducted to measure $p_{\mathrm{s}}$. For case $\mathrm{C} 1$, a stainless plate $(t=0.3 \mathrm{~mm})$ was used to confine swelling deformation. For case $\mathrm{C} 2$, another stainless plate $(t=2 \mathrm{~mm})$ was fixed to the X-ray tunnel area. For

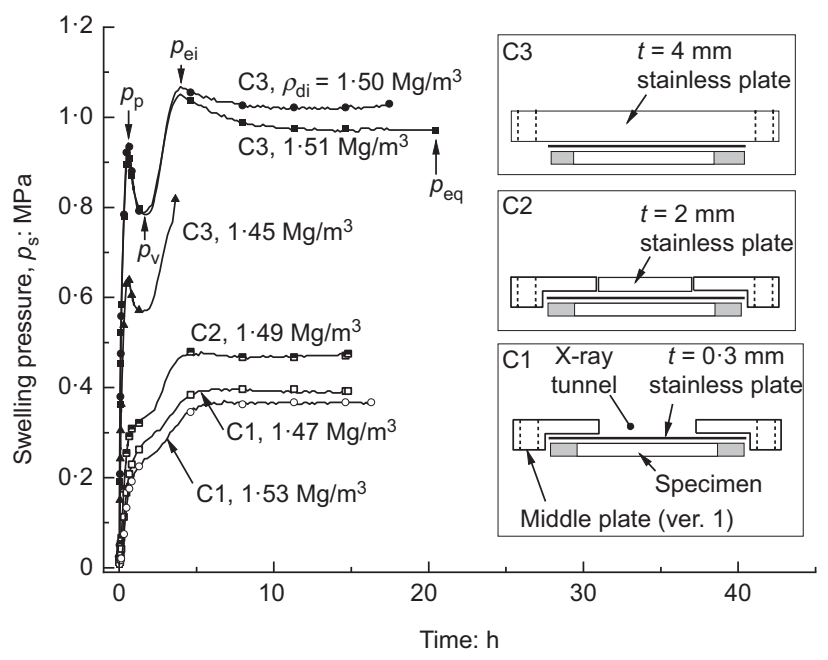

Fig. 4. Swelling pressure trial tests with the swelling pressure cell

case 3, the middle plate was replaced by a stainless plate $(t=4 \mathrm{~mm})$. K_V1 specimens with initial dry density $\left(\rho_{\mathrm{di}}\right)$ of $\sim 1.50 \mathrm{Mg} / \mathrm{m}^{3}$ were prepared. The results are presented in Fig. 4. Apparently, $p_{\mathrm{s}}$ time history curves obtained in cases 1 and 2 differ from those in case 3 . In case $3, p_{\mathrm{s}}$ experiences four stages during wetting: it first increases sharply to a maximum (peak swelling pressure, $p_{\mathrm{p}}$ ), drops to a minimum (valley swelling pressure, $p_{\mathrm{v}}$ ), climbs to another maximum (initial swelling pressure for equilibrium, $p_{\mathrm{ei}}$ ) and finally reaches an equilibrium state (equilibrium swelling pressure, $p_{\text {eq }}$ ). The expressions just given in parentheses are the names 
of feature points of the $p_{\mathrm{s}}$ curve for convenience, as shown also in Fig. 4. These features have often been observed in past studies, although specimens were often of $\phi=28-60 \mathrm{~mm}$ and $t=10-20 \mathrm{~mm}$ (e.g. Pusch, 1980; Komine, 2004; Sun et al., 2013; Wang et al., 2020a). For cases 1 and 2, $p_{\mathrm{p}}$ and $p_{\mathrm{v}}$ are not observed clearly. The reason for the drop in $p_{\mathrm{s}}$ is explained in later sections, whereas, under the weaker confining conditions in cases 1 and 2, large swelling deformation seems to be responsible for invisibility of $p_{\mathrm{v}}$ and for markedly smaller $p_{\text {eq }}$. With the latest version of the cell, feature points can be observed clearly, as described in later sections.

In considering that the water supply system (groove, filter paper and mesh) in Fig. 3 might not transfer water uniformly to the central part of the specimen, the water content $(w)$ distribution was measured for some specimens after the tests in Fig. 4. The $w$ measurements are presented in Fig. 5. Three specimens in cases $\mathrm{C} 1$ and $\mathrm{C} 2$ were cut using a circular cutter into three parts, for which $w$ at the centre part is $1-3 \%$ higher than other parts. The higher $w$ at the centre part would be attributed to relatively higher swelling deformation when compared to other parts. One specimen in $\mathrm{C} 3$, for which the test was terminated when $p_{\mathrm{s}}$ approached $p_{\mathrm{ei}}$, was cut into five parts, where the $w$ difference was about $3 \%$. However, it seems $w$ at the centre is not necessarily lower than other parts. This difference might also be affected partially by the $w$ measurement accuracy for small samples. Fig. 5 suggests that the current water supply system might induce $w$ distribution variation up to $\pm 1 \cdot 5 \%$. Data are not available for comparison with other water supply systems, while the fact observed during tests that $p_{\mathrm{s}}$ increased immediately after water supply implies that the system might not affect $p_{\mathrm{s}}$ measurement to any great degree.

Another technical issue is related to effects of the Be plate and polyester film on the X-ray profile. For parallel beam $\mathrm{XRD}$, in principle, the Be plate and polyester film placed on the specimen top surface (Fig. 3) would not affect the $\theta_{\mathrm{pk}}$ position. Some tests were conducted to confirm that fact. Fig. 6(a) shows three X-ray profiles of a compacted K_V1 specimen with $w=7 \cdot 2 \%$ (i.e. water content in the laboratory environment). The top profile was obtained when the specimen was not covered by a Be plate. For the middle one, a Be plate $(t=0.3 \mathrm{~mm})$ was placed on the specimen top surface and the vertical axis origin of the diffractometer $(z=0)$ was set at the specimen surface. For the bottom one, $z=0$ was

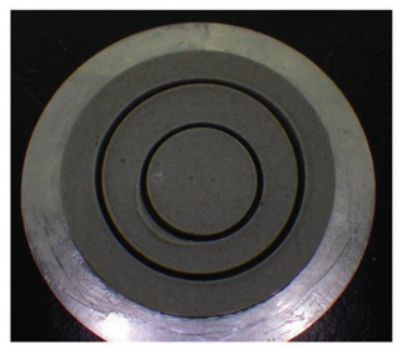

Cutting for specimens in $\mathrm{C} 1$ and $\mathrm{C} 2$

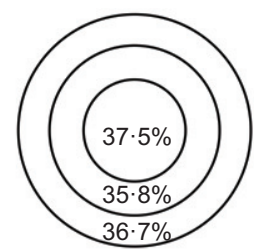

$\mathrm{C} 1,1 \cdot 47 \mathrm{Mg} / \mathrm{m}^{3}$

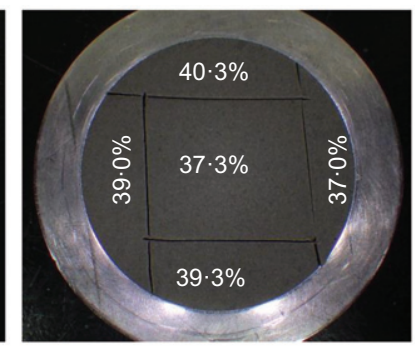

Cutting for specimen in C3, $1 \cdot 45 \mathrm{Mg} / \mathrm{m}^{3}$

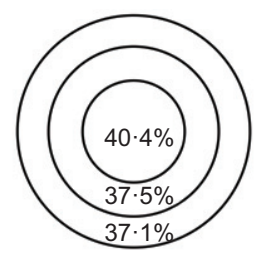

C1, $1.53 \mathrm{Mg} / \mathrm{m}^{3}$

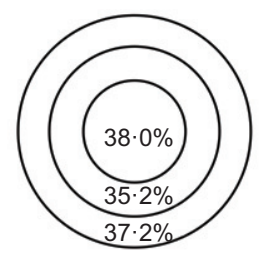

$\mathrm{C} 2,1.49 \mathrm{Mg} / \mathrm{m}^{3}$
Fig. 5. Water content distribution measured after swelling pressure tests set at the Be plate surface (default setting for the diffractometer). Note that the $y$-axis scales of profiles were arbitrarily adjusted for visual convenience (i.e. arbitrary scale) for Fig. 6(a) and other figures without showing the $y$-axes. Compared to $2 \theta_{\mathrm{pk}}$ of the top profile, $2 \theta_{\mathrm{pk}}$ is $0 \cdot 05^{\circ}$ smaller for the middle one and $0.25^{\circ}$ smaller for the bottom one. In terms of $d_{001}$, they are, respectively, $1 \cdot 26 \mathrm{~nm}$, $1.27 \mathrm{~nm}$ and $1.30 \mathrm{~nm}$. Figure $6(\mathrm{~b})$ shows another example for a K_V1 specimen with $w=51 \cdot 3 \%$. The specimen was covered by a polyester film to avoid water evaporation during scanning to obtain the top profile. Then either a $t=0.1 \mathrm{~mm}$ or a $0.15 \mathrm{~mm}$ Be plate was added to obtain the other two profiles ( $z=0$ at the specimen surface). The value of $2 \theta_{\mathrm{pk}}$ increases from $4.58^{\circ}$ to $4.63^{\circ}$ by adding Be plates, which is opposite to that in Fig. 6(a). The reason remains unclear, but instrumental error at a small angle and broad peak for clayey minerals are possible reasons. The fact that background noise makes an exact determination of the $\theta_{\mathrm{pk}}$ position difficult is also a possible reason. For this study, $z=0$ was set at the specimen surface, except when presented specifically otherwise. Also, Fig. 6(b) shows that the peak at $2 \theta_{\mathrm{pk}}=2 \cdot 3^{\circ}$ cannot be observed clearly by adding Be plates, although it was improved by placement of a thinner plate (i.e. $0 \cdot 1 \mathrm{~mm}$ ).

An example demonstrating the effect of a polyester film $(t=6 \mu \mathrm{m})$ on a $\mathrm{K}_{-} \mathrm{V} 1$ specimen with $w$ in a laboratory environment (i.e. it is expected that evaporation can be ignored during scanning) is presented in Fig. 6(c). Results show that $2 \theta_{\mathrm{pk}}$ is $0.04^{\circ}$ smaller by adding the polyester film. In addition, Fig. 6(d) presents results for a K_V1 specimen with $w=47 \cdot 1 \%$. The profile was taken first for the case without the polyester film; then the film was placed for another profile. During the first scanning, $w$ would be smaller somehow because of water evaporation (i.e. scanning time was $\sim 2.5 \mathrm{~min}$ ), which is expected to result in a larger $2 \theta_{\mathrm{pk}}$ during later scanning. However, $2 \theta_{\mathrm{pk}}$, after covering with polyester film, moves from 4.66 to $4.57^{\circ}$ (i.e. $\sim 0 \cdot 1^{\circ}$ smaller) and from $2 \cdot 45^{\circ}$ to $2 \cdot 25^{\circ}$ (i.e. $\sim 0 \cdot 2^{\circ}$ smaller). Be plate or polyester films (e.g. Mylar film) as an XRD window have often been used to maintain constant water content (Foster et al., 1954; Fink et al., 1968; Ravina \& Low, 1972; Viani et al., 1983; Zhang \& Low, 1989). However, the present authors were unable to ascertain any particular reasons for the results in Fig. 6. In this study, the film continued to be used in all tests described in later sections to avoid water evaporation and Be plate erosion, although the measured $2 \theta_{\mathrm{pk}}$ might differ slightly from its true value.

\section{Testing programmes}

$\mathrm{X}$-ray scanning was conducted during water absorption while measuring $p_{\mathrm{s}}$ for four compacted $\mathrm{K} \_\mathrm{V} 1$ specimens (hereinafter termed the XRD- $p_{\mathrm{s}}$ test). The specimen and diffractometer information are presented in Table 1. The K_V1 was first oven-dried at $110^{\circ} \mathrm{C}$ for $24 \mathrm{~h}$, and then it was statically compacted into the specimen ring using a jack. The final dry density $\left(\rho_{\mathrm{df}}\right)$ was estimated from the $p_{\mathrm{s}}$ measurement, as explained in later sections. An X-ray diffractometer (RINT-TTR III, Rigaku Corp.) with a parallel $\mathrm{Cu} \mathrm{K} \alpha$ beam (source power: $50 \mathrm{kV}$ and $300 \mathrm{~mA}$ ) was used for this study. Note that the parallel beam, which was developed based on a multilayer technique recently (Harada, 2003), should have a better performance than Bragg-Brentano geometry (BB geometry), which is a popular geometry in powder XRD, in terms of accuracy for low diffraction angles; this is because $\mathrm{BB}$ geometry involves some assumptions that are expected to induce more measurement error (e.g. Dinnebier \& Billinge, 2008). Scanning speed was $1 \%$ min initially because the profiles changed rapidly at the initial stage of water 


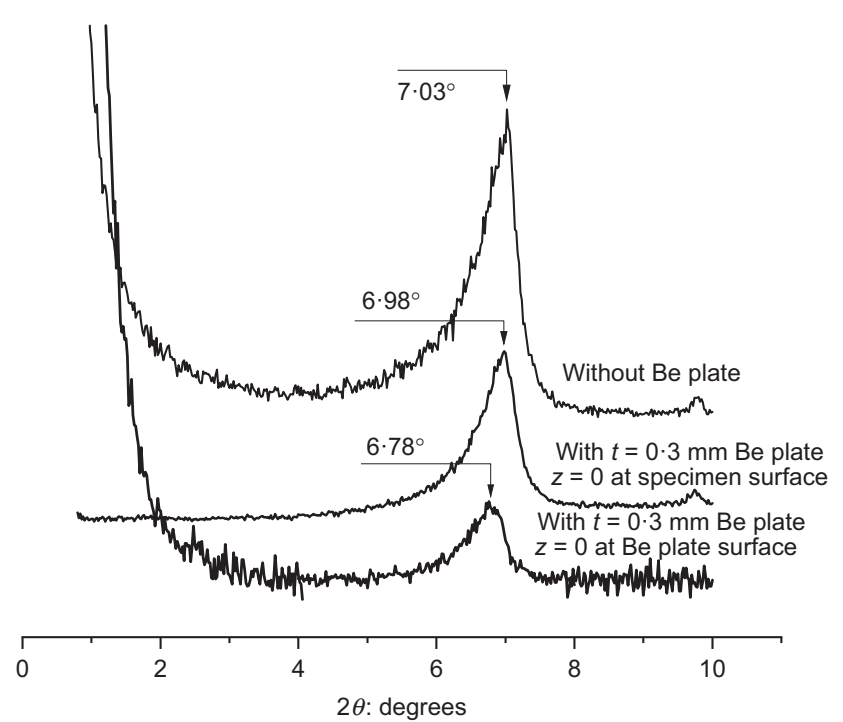

(a)

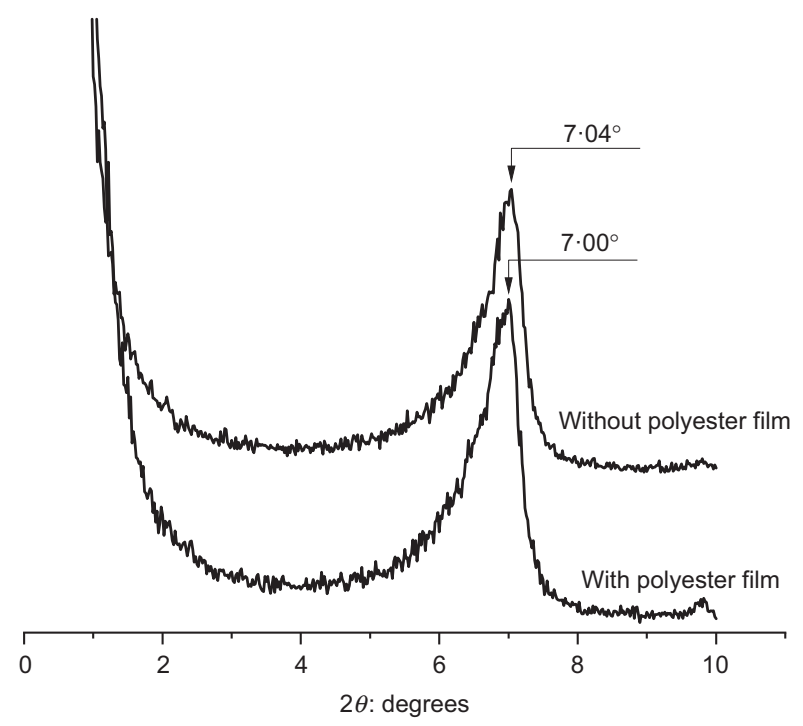

(c)

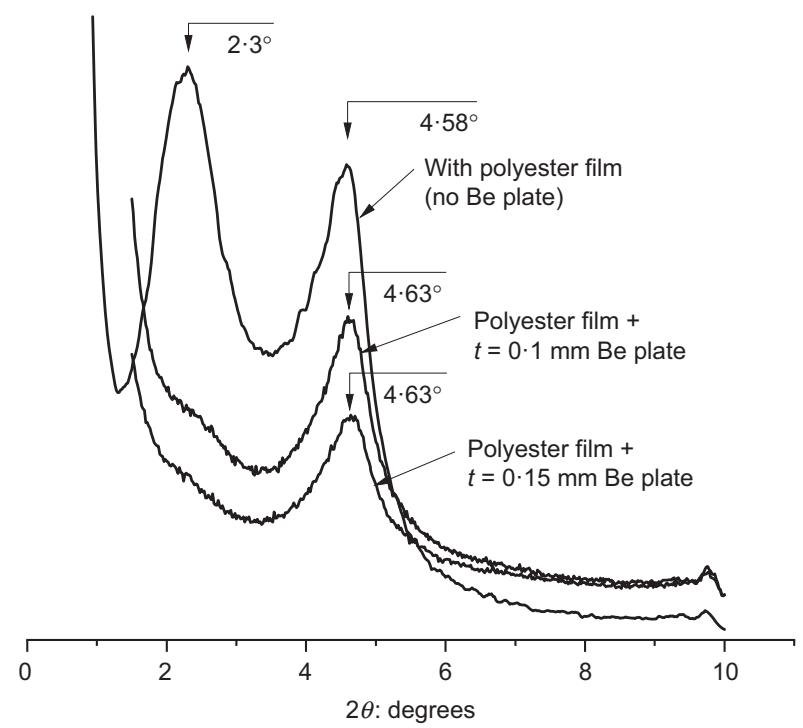

(b)

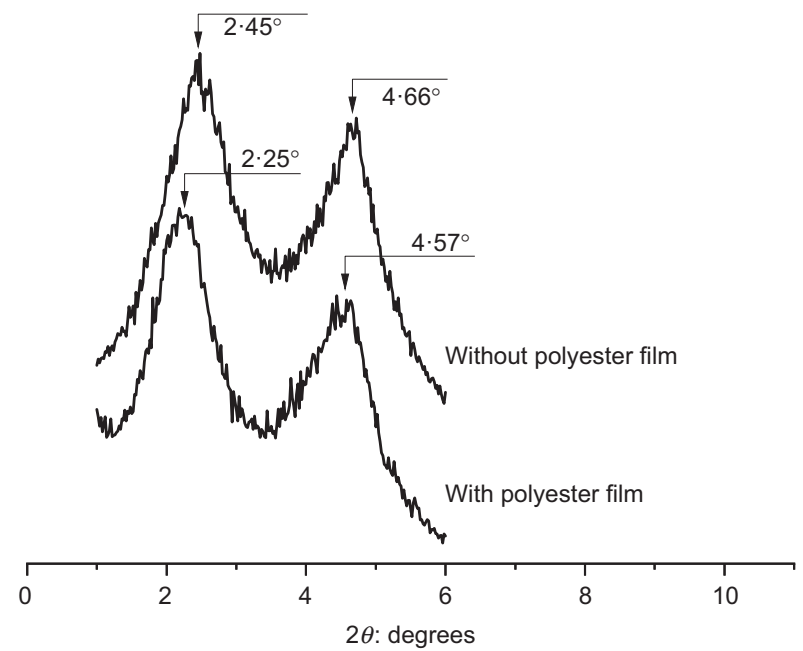

(d)

Fig. 6. XRD profiles for specimens with different testing configurations: $K_{-} V 1$ specimens with or without covering Be plate: (a) $w=7 \cdot 2 \%$ and (b) $w=51 \cdot 3 \%$; and K_V1 specimens with or without covering polyester film: (c) $w=7-9 \%$ and (d) $w=47 \cdot 1 \%$

Table 1. Specimen conditions and X-ray diffractometer setting for XRD- $p_{\mathrm{s}}$ tests

\begin{tabular}{l|c|c|c|c|l}
\hline Test no. & $w_{\mathrm{i}}: \%$ & $\rho_{\mathrm{di}}: \mathrm{Mg} / \mathrm{m}^{3}$ & $w_{\mathrm{f}}: \%$ & $\rho_{\mathrm{df}}: \mathrm{Mg} / \mathrm{m}^{3}$ & X-ray diffractometer setting \\
\hline XRD- $p_{\mathrm{s} \_} 1$ & 0 & $1 \cdot 29$ & $50 \cdot 7$ & $1 \cdot 26$ & Source: parallel Cu K $\alpha$ beams \\
XRD- $p_{\mathrm{s}-2}$ & 0 & $1 \cdot 40$ & $45 \cdot 7$ & $1 \cdot 28$ & Divergence slit (DS): $1 \mathrm{~mm}$ \\
XRD- $p_{\mathrm{s}-3}$ & 0 & $1 \cdot 51$ & $39 \cdot 9$ & $1 \cdot 34$ & Scattering slits (SS): $1 \mathrm{~mm}$ \\
XRD- $p_{\mathrm{s} \_} 4$ & 0 & $1 \cdot 70$ & $32 \cdot 5$ & $1 \cdot 43$ & Receiving slit (RS): $1 \mathrm{~mm}$ \\
\hline
\end{tabular}

Note: $w_{\mathrm{i}}$, initial water content; $\rho_{\mathrm{df}}$, initial dry density; $w_{\mathrm{f}}$, final water content; $\rho_{\mathrm{df}}$, final dry density calculated from equilibrium swelling pressure $p_{\text {eq }}$

absorption. This was changed to 0.5 or $0.2 \%$ min later for smoothing profiles. For each test, an initial profile before water supply was taken. After achieving $p_{\text {eq }}$, the specimen was taken out and scanned by removing the Be plate (the polyester film was retained), and this is assigned as the final profile. All X-ray scanning angles were between $2 \theta=0 \cdot 8$ and $10^{\circ}$ by rotating incident and detector sides and keeping the specimen horizontal (Fig. 3); this scan range was chosen because the XRD peak of montmorillonite in this range is much easier to distinguish than the one between $2 \theta=60$ and $65^{\circ}$ (e.g. Ravina \& Low, 1977).

In addition to the XRD- $p_{\mathrm{s}}$ test, a series of swelling pressure tests were also conducted with the pressure cell, for which X-ray scanning was not applied. In this testing programme, the cell was simplified further as illustrated in Fig. 7. The middle plate, mesh and filter paper were removed. Instead, membrane filters $(t=0 \cdot 14 \mathrm{~mm})$ with $0.45 \mu \mathrm{m}$ pore size were used (Wang et al., 2017). The testing programme is shown in 


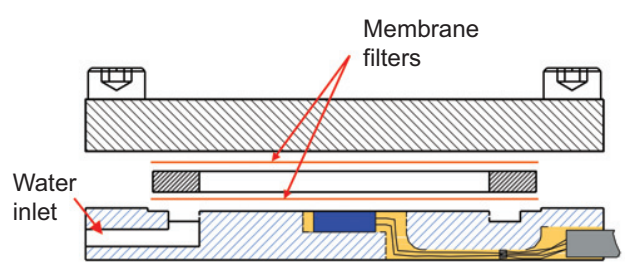

Fig. 7. Schematic illustration of the pressure cell for swelling pressure measurement

Table 2. Specimen conditions for swelling pressure tests

\begin{tabular}{|c|c|c|c|c|c|}
\hline $\begin{array}{l}\text { Group } \\
\text { no. }\end{array}$ & $w_{\mathrm{i}}: \%$ & $\begin{array}{c}\rho_{\mathrm{di}}: \\
\mathrm{Mg} / \mathrm{m}^{3}\end{array}$ & $w_{\mathrm{f}}: \%$ & $\begin{array}{c}\rho_{\mathrm{df}}: \\
\mathrm{Mg} / \mathrm{m}^{3}\end{array}$ & $\begin{array}{l}p_{\mathrm{eq}}: \\
\mathrm{MPa}\end{array}$ \\
\hline \multirow[t]{4}{*}{$p_{\mathrm{s}-1} 1$} & \multirow[t]{4}{*}{$7 \cdot 10$} & $1 \cdot 355$ & $38 \cdot 1$ & $1 \cdot 343$ & 0.51 \\
\hline & & $1 \cdot 552$ & $33 \cdot 1$ & 1.499 & $1 \cdot 26$ \\
\hline & & $1 \cdot 683$ & $28 \cdot 2$ & 1.600 & $1 \cdot 74$ \\
\hline & & $1 \cdot 859$ & $24 \cdot 7$ & 1.720 & $4 \cdot 54$ \\
\hline \multirow[t]{4}{*}{$p_{\mathrm{s} \_} 2$} & \multirow[t]{4}{*}{$8 \cdot 85$} & $1 \cdot 363$ & $34 \cdot 7$ & $1 \cdot 341$ & 0.56 \\
\hline & & $1 \cdot 571$ & $29 \cdot 3$ & $1 \cdot 510$ & $1 \cdot 28$ \\
\hline & & 1.698 & $26 \cdot 0$ & $1 \cdot 602$ & $2 \cdot 15$ \\
\hline & & $1 \cdot 839$ & $23 \cdot 0$ & 1.684 & $3 \cdot 86$ \\
\hline \multirow[t]{4}{*}{$p_{\mathrm{s} \_} 3$} & \multirow[t]{4}{*}{$7 \cdot 85$} & $1 \cdot 485$ & $32 \cdot 0$ & $1 \cdot 452$ & 0.94 \\
\hline & & 1.608 & $28 \cdot 1$ & $1 \cdot 569$ & $1 \cdot 83$ \\
\hline & & $1 \cdot 662$ & $27 \cdot 7$ & $1 \cdot 576$ & $2 \cdot 15$ \\
\hline & & $1 \cdot 767$ & $25 \cdot 8$ & 1.653 & $2 \cdot 83$ \\
\hline \multirow[t]{4}{*}{$p_{\mathrm{s} \_} 4$} & \multirow[t]{4}{*}{$7 \cdot 70$} & $1 \cdot 445$ & $31 \cdot 8$ & 1.420 & 0.77 \\
\hline & & $1 \cdot 590$ & $29 \cdot 6$ & $1 \cdot 526$ & $1 \cdot 51$ \\
\hline & & 1.639 & $29 \cdot 4$ & $1 \cdot 567$ & $1 \cdot 84$ \\
\hline & & $1 \cdot 756$ & $24 \cdot 8$ & 1.631 & $2 \cdot 85$ \\
\hline \multirow[t]{4}{*}{$p_{\mathrm{s} \_} 5$} & \multirow[t]{4}{*}{$7 \cdot 67$} & $1 \cdot 494$ & $30 \cdot 6$ & $1 \cdot 456$ & 0.96 \\
\hline & & $1 \cdot 613$ & $28 \cdot 9$ & $1 \cdot 540$ & $1 \cdot 60$ \\
\hline & & $1 \cdot 726$ & $25 \cdot 5$ & $1 \cdot 621$ & 2.53 \\
\hline & & $1 \cdot 817$ & $23 \cdot 7$ & 1.672 & $3 \cdot 29$ \\
\hline \multirow[t]{4}{*}{$p_{\mathrm{s} \_} 6$} & \multirow[t]{4}{*}{$7 \cdot 47$} & 0.995 & $61 \cdot 2$ & 0.993 & $0 \cdot 25$ \\
\hline & & $1 \cdot 125$ & $51 \cdot 6$ & $1 \cdot 118$ & 0.32 \\
\hline & & $1 \cdot 237$ & $44 \cdot 0$ & $1 \cdot 233$ & $0 \cdot 43$ \\
\hline & & $1 \cdot 392$ & $38 \cdot 9$ & $1 \cdot 372$ & $0 \cdot 72$ \\
\hline \multirow[t]{4}{*}{$p_{\mathrm{s} \_} 7$} & \multirow[t]{4}{*}{$7 \cdot 66$} & $1 \cdot 041$ & $59 \cdot 5$ & $1 \cdot 041$ & $0 \cdot 28$ \\
\hline & & $1 \cdot 189$ & $46 \cdot 3$ & $1 \cdot 185$ & 0.37 \\
\hline & & $1 \cdot 345$ & $37 \cdot 1$ & $1 \cdot 333$ & $0 \cdot 60$ \\
\hline & & $1 \cdot 466$ & $33 \cdot 4$ & 1.439 & 0.98 \\
\hline
\end{tabular}

Note: $w_{\mathrm{i}}$, initial water content; $\rho_{\mathrm{df}}$, initial dry density; $w_{\mathrm{f}}$, final water content; $\rho_{\mathrm{df}}$, final dry density; $p_{\mathrm{eq}}$, equilibrium swelling pressure.

Table 2. Four pressure cells were used to conduct tests simultaneously as a group; seven groups were examined. Specimens were prepared similarly by static compaction. The specimen surfaces were trimmed after compaction to leave an equal thickness to that of the specimen ring. All mass measurements were conducted on a balance with a resolution of $0 \cdot 1 \mathrm{mg}$. All length measurements (e.g. $t$ and $\phi$ of specimen ring) were accurate to $1 \mu \mathrm{m}$. The initial dry density $\left(\rho_{\mathrm{di}}\right)$ was calculated as $M / V /\left(1+w_{\mathrm{i}} / 100\right)$, where $M$ and $V$, respectively, represent the specimen mass and the specimen ring volume. To estimate the specimen dry density after tests $\left(\rho_{\mathrm{df}}\right)$, the $t$ value of the cell (i.e. distance between centres of the top surface of the top plate and the bottom surface of the base plate) was measured immediately before water supply and before dismantling the cell using a micrometer, and the $t$ values of the membrane filters were also measured before and after tests. The relations between measured $p_{\text {eq }}$ and $t$ changes of the cell and membranes are shown in Fig. 8. The pressure cell expansion is linearly proportional to $p_{\mathrm{eq}}$; membrane filter compression is a quadratic function relation with $p_{\text {eq }}$. Both pressure cell expansion and membrane filter compression were regarded as results of specimen swelling deformation

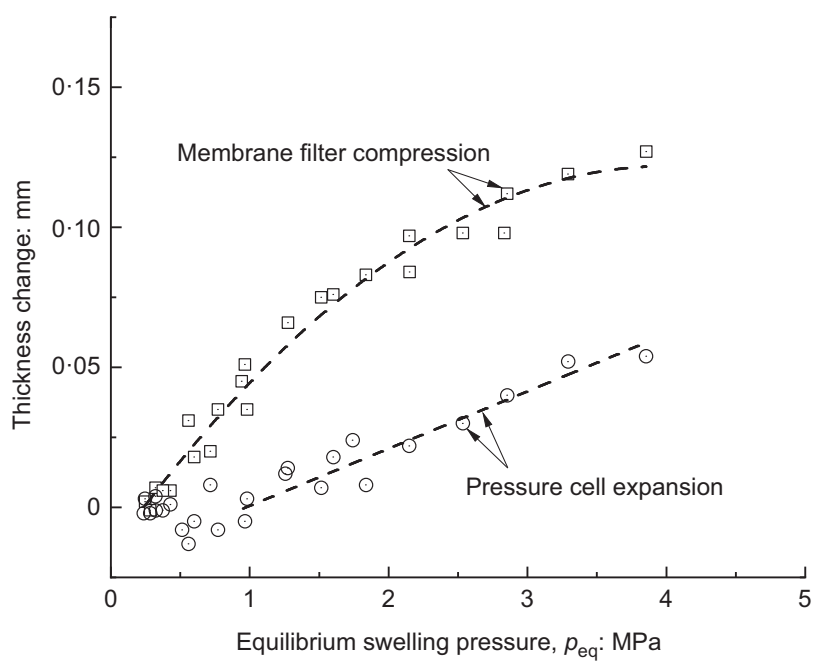

Fig. 8. Membrane filter compression and pressure cell expansion observed during swelling pressure test

and were considered in the $\rho_{\mathrm{df}}$ calculation. The pressure cell expansion for group 3 and the membrane filter compression for group 1 were not measured, but were estimated using the relations in Fig. 8.

\section{TEST RESULTS AND DISCUSSION \\ Results of XRD- $\mathrm{p}_{s}$ tests}

Figure 9 presents results of the XRD- $p_{\mathrm{s}}$ test obtained for four specimens. Each figure part (Figs 9(a)-9(d)) has three components: the $p_{\mathrm{s}}$ time history at the top, typical profiles at the bottom, and an inset graph. The XRD scanned points are indicated on the $p_{\mathrm{s}}$ curve by empty circles and numbered from no. 1, which is the initial profile before supplying water. The closest profiles to the feature points $\left(p_{\mathrm{p}}, p_{\mathrm{v}}, p_{\mathrm{ei}}\right.$ and $\left.p_{\mathrm{eq}}\right)$ of the $p_{\mathrm{s}}$ curve are also shown. Typical profiles show that the profile peak starts from $2 \theta_{\mathrm{pk}}=9^{\circ}$, which corresponds to a $d_{001}$ value of $0.98 \mathrm{~nm}$. The peak moves to $2 \theta_{\mathrm{pk}}=7^{\circ}\left(d_{001}=1.26 \mathrm{~nm}\right)$ immediately after water supply. Thereafter, it moves to $2 \theta_{\mathrm{pk}}=5.6^{\circ}\left(d_{001}=1.58 \mathrm{~nm}\right)$ and $2 \theta_{\mathrm{pk}}=4.7^{\circ}\left(d_{001}=1.90 \mathrm{~nm}\right)$. Here, as also shown in Fig. $1(\mathrm{~b}), d_{001}=0.98 \mathrm{~nm}, 1.26 \mathrm{~nm}, 1.58 \mathrm{~nm}$ and $1.90 \mathrm{~nm}$ are typical values observed in past studies, which were interpreted as four hydration states of exchangeable ions or states with $0-3$ layers of water molecules (i.e. layer of water $L=0 \mathrm{w}, 1 \mathrm{w}, 2 \mathrm{w}$ and $3 \mathrm{w}$, respectively) in the interlayer space of montmorillonite (e.g. Moore \& Hower, 1986; Watanabe \& Sato, 1988; Sato et al., 1992; Yamada et al., 1994; Morodome \& Kawamura, 2009; Wang et al., 2020a). Between two consecutive $L$ states, transition profiles are observed either as very broad peaks (e.g. no. 3 in Fig. 9(a)) or bimodal peaks (e.g. no. 9 in Fig. 9(a)). These transition states are expected to be very short in terms of $w$ range because, in most cases, unimodal peaks with $2 \theta_{\mathrm{pk}}$ at one of four $L$ states were observed for K_V1 with different $w$ (Fig. 1(b)). With these transition profiles, intensity growth at $L=2 \mathrm{w}$ and $L=3 \mathrm{w}$ are clearly visible, implying heterogeneity (i.e. co-existence) of $L$ states during water absorption (Cases et al., 1992; Ferrage et al., 2005; Warr \& Berger, 2007; Holmboe et al., 2012).

After reaching the maximum intensity at $2 \theta_{\mathrm{pk}}=4.7^{\circ}$ (no. 16, 16, 17 and 24 for Figs 9(a), 9(b), 9(c) and 9(d), respectively), the reductions associated with intensity increase at $2 \theta=2-3^{\circ}$ (inset figures). These intensity increases become weaker as the specimen density increases. For the $\rho_{\mathrm{di}}=1.70 \mathrm{Mg} / \mathrm{m}^{3}$ specimen, only a very small reduction at 


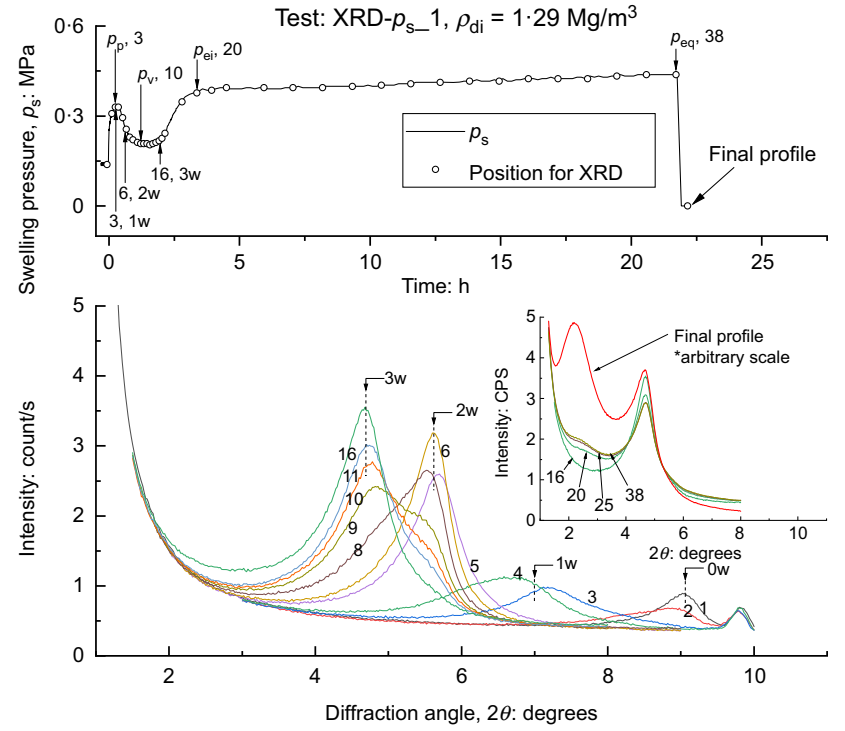

(a)
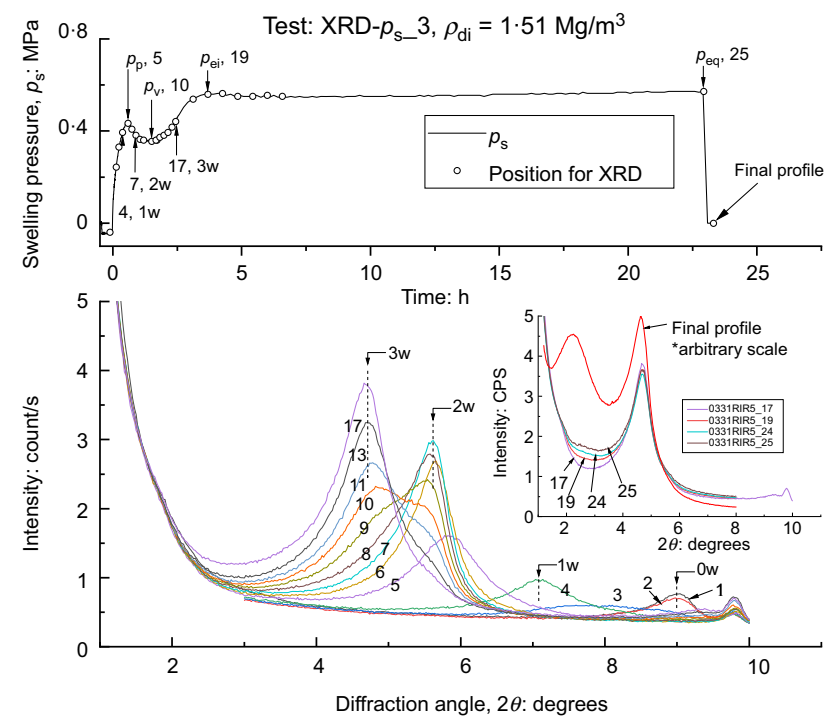

(c)
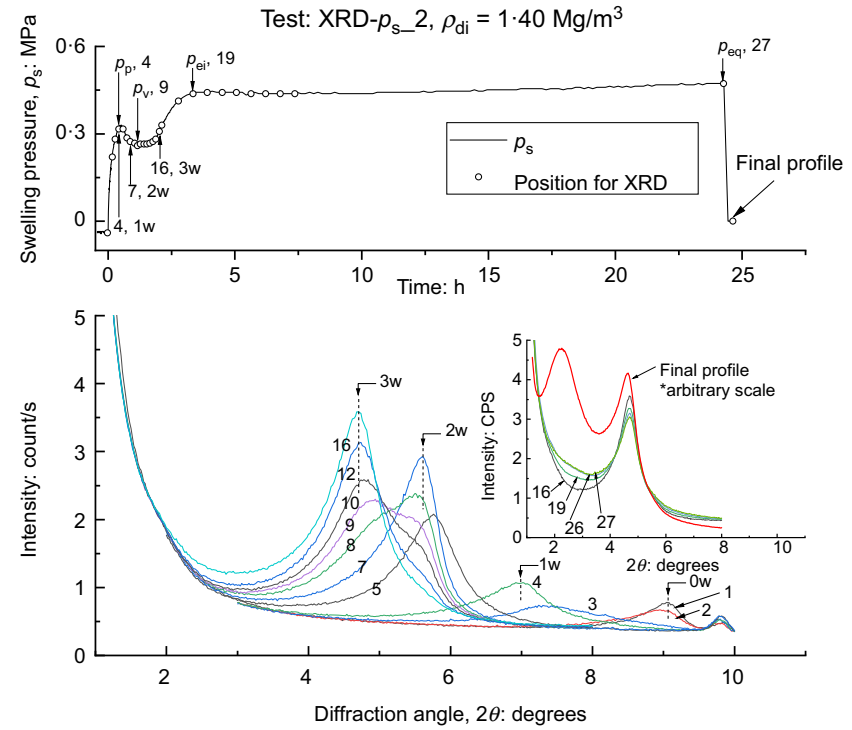

(b)
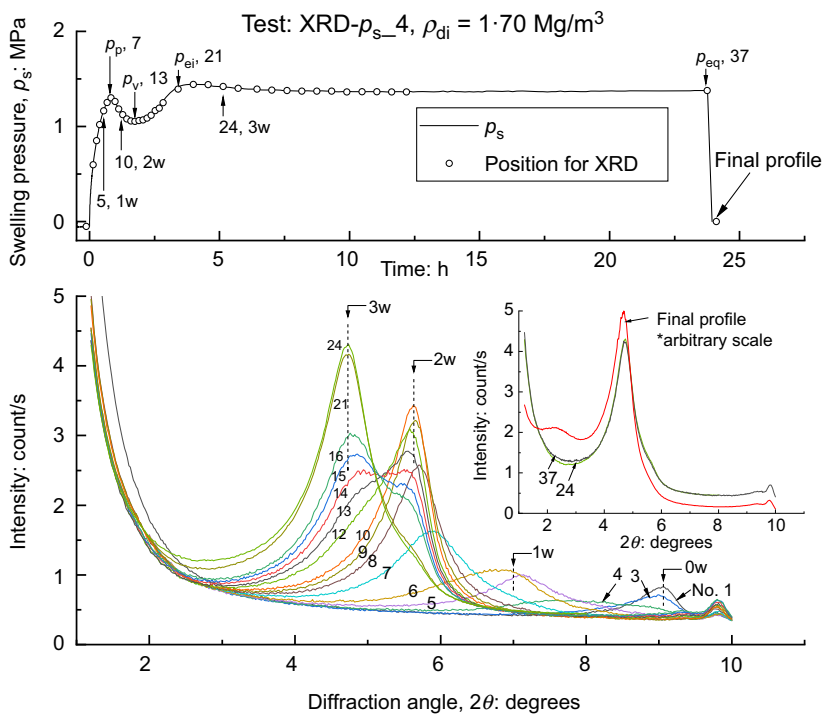

(d)

Fig. 9. Schematic illustration of the behaviours of compacted bentonite: (a) test: $X R D-p_{\mathrm{s} \_} 1, \rho_{\mathrm{di}}=1 \cdot 29 \mathrm{Mg} / \mathrm{m}^{3} ;$ (b) test: $\mathrm{XRD}-p_{\mathrm{s} \sim} 2$, $\rho_{\mathrm{di}}=1 \cdot 40 \mathrm{Mg} / \mathrm{m}^{3}$; (c) test: XRD- $p_{\mathrm{s} \_} 3, \rho_{\mathrm{di}}=1.51 \mathrm{Mg} / \mathrm{m}^{3} ;$ (d) test: XRD- $p_{\mathrm{s} \_} 4, \rho_{\mathrm{di}}=1 \cdot 70 \mathrm{Mg} / \mathrm{m}^{3}$

$2 \theta_{\mathrm{pk}}=4 \cdot 7^{\circ}$ and increase at $2 \theta=2-3^{\circ}$ are observed. The final profiles (i.e. profiles after removing swelling pressure and $\mathrm{Be}$ plate at the end of the tests) are also added to the inset figures. Note that the final profiles are of different intensity scale from those obtained during water supply. Bimodal peaks at $2 \theta_{\mathrm{pk}}=4.7^{\circ}$ and $\sim 2 \cdot 2^{\circ}\left(d_{001}=\sim 4.0 \mathrm{~nm}\right)$ are observed from these final profiles, of which the major peak in terms of intensity magnitude changes from $2 \theta_{\mathrm{pk}}=\sim 2 \cdot 2^{\circ}$ to $2 \theta_{\mathrm{pk}}=4 \cdot 7^{\circ}$ as the specimen becomes denser. It is expected that the intensity growth at $2 \theta=2-3^{\circ}$ during water absorption corresponds to peaks $2 \theta_{\mathrm{pk}}=\sim 2.2^{\circ}$ on the final profile, which is evidenced by Fig. 6(b). The initiation time of the peak at $2 \theta_{\mathrm{pk}}=\sim 2 \cdot 2^{\circ}$ is not clear, while from the evolution process of the peak from $2 \theta_{\mathrm{pk}}=5 \cdot 6^{\circ}$ to $2 \theta_{\mathrm{pk}}=4 \cdot 7^{\circ}$, where no clear peak at $4 \cdot 7^{\circ}$ exists before the peak intensity at $5 \cdot 6^{\circ}$ reaches its maximum, one might infer that the peak component at $2 \theta_{\mathrm{pk}}=\sim 2 \cdot 2^{\circ}$ is not significant before the peak intensity reaches its maximum at $4 \cdot 7^{\circ}$.

The $p_{\mathrm{s}}$ position corresponding to profiles with maximum intensities at $1 \mathrm{w}, 2 \mathrm{w}$ and $3 \mathrm{w}$ are shown on the $p_{\mathrm{s}}$ curve. It is revealed that during movement of the profile peak from $0 \mathrm{w}$ to $1 \mathrm{w}, p_{\mathrm{s}}$ reaches $p_{\mathrm{p}}$ for relatively loose specimens, while $p_{\mathrm{p}}$ is reached during profile peak movement from $1 \mathrm{w}$ to $2 \mathrm{w}$ for relatively dense specimens. The $p_{\mathrm{v}}$ appears as the profile peak moves from $2 \mathrm{w}$ to $3 \mathrm{w} ; p_{\text {ei }}$ in most cases is achieved after the profile peak reaches maximum intensity at $3 \mathrm{w}$, while as the specimen density increases, $p_{\text {ei }}$ may also appear before that. It is clear from Fig. 9 that $d_{001}$ monotonically increases during water absorption, whereas $p_{\mathrm{s}}$ drops to $p_{\mathrm{v}}$ and then increases again to $p_{\mathrm{ei}}$. It is implied that $p_{\mathrm{s}}$ reduction would be a result of interparticle force reduction rather than force reduction between montmorillonite crystalline layers. These behaviours may be explained schematically by Fig. 10, wherein the montmorillonite particle is symbolised by a spring with arrows and the arrows indicate interparticle force. Initially, the skeleton of non-swelling particles maintains its initial configuration and $p_{\mathrm{s}}$ increases due to swelling of montmorillonite. When $p_{\text {s }}$ reaches a certain magnitude, some particles may move to less stressed positions, which results in a reduction in $p_{\mathrm{s}}$ (i.e. reduction of interparticle force). When 


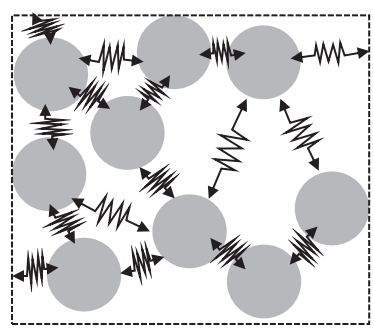

(a)

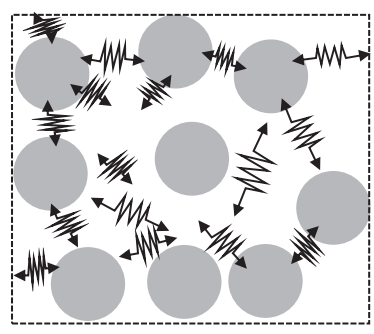

(b)

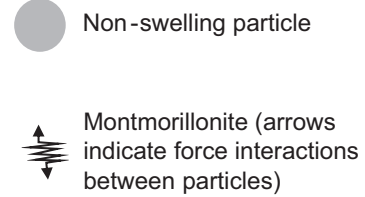

between particles)

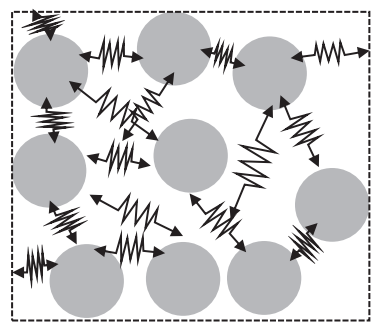

(c)

Fig. 10. Schematic illustration of behaviours of compacted bentonite. (a) $p_{\mathrm{s}}$ from 0 to $p_{\mathrm{p}}$ : increases due to swelling of montmorillonite. (b) $p_{\mathrm{s}}$ from $p_{\mathrm{p}}$ to $p_{\mathrm{v}}$ : reduction due to movement of particles resulting in reduction of interparticle force. (c) $p_{\mathrm{s}}$ from $p_{\mathrm{v}}$ to $p_{\mathrm{ei}}$ : re-increase due to further swelling and limited movement space

the stress environment inside a specimen becomes uniform, further swelling of montmorillonite causes instances of $p_{\mathrm{s}}$ increasing again. With these considerations, a relatively wider $p_{\mathrm{v}}$ area (or longer duration around $p_{\mathrm{v}}$ ) for a looser specimen (e.g. Fig. 9(a)) is reasonable, since particle movement can be more active in a relatively larger void space compared to a denser specimen. The last profiles during water supply and the final profiles were extracted and are plotted in Fig. 11. It can be observed that $2 \theta_{\mathrm{pk}}$ at $3 \mathrm{w}$ is about $0.05^{\circ}$ smaller by removing the Be plate and $p_{\mathrm{s}}$, which would be a result of the Be plate effect on $2 \theta_{\mathrm{pk}}$ (i.e. $d_{001}$ did not increase significantly at $3 \mathrm{w}$ by releasing $p_{\mathrm{s}}$ ), as illustrated in Fig. 6(b). This observation also suggests that montmorillonite swelling up to $3 \mathrm{w}$ should not have been obstructed during water absorption.

As described in Fig. 1, swelling of montmorillonite was classified into crystalline swelling and osmotic swelling at $d_{001}=\sim 4 \cdot 0 \mathrm{~nm}$ (Norrish, 1954; Meleshyn \& Bunnenberg, 2005). According to the authors surveyed, this classification was mainly based on the observed stepwise or linear relation between $d_{001}$ and $w$, thus no clear evidence is available to define montmorillonite behaviours for $d_{001}$ between $\sim 1.9 \mathrm{~nm}$ and $\sim 4.0 \mathrm{~nm}$, because peaks on X-ray profiles corresponding to this range were rarely clearly observed (Anderson et al., 2010). This gap (i.e. $d_{001}$ between $\sim 1.9 \mathrm{~nm}$ and $\sim 4.0 \mathrm{~nm}$ ) was called the forbidden basal spacing by Ravina \& Low (1977). Meleshyn \& Bunnenberg (2005) studied the mechanism of the forbidden layer spacing of a Na-montmorillonite by the Monte Carlo approach, from which they concluded that a special chain structure would exist between $\mathrm{Na}$ ion and water molecule formed at $d_{001}=\sim 1.9 \mathrm{~nm}$. The structure locked further increase of $d_{001}$ until $w$ increased to a critical level. When $w$ increased further, those chain structures broke, the interlayer space opened to absorb those water molecules and $d_{001}$ jumped to $\sim 4.0 \mathrm{~nm}$. The forbidden basal spacing is important for this study because $2 \theta_{\mathrm{pk}}$ at $\sim 2 \cdot 2^{\circ}$ (Fig. 11) indicates that the maximum $d_{001}$ (i.e. maximum swelling) for tested specimens under confined condition would be about $4.0 \mathrm{~nm}$ (the calculated $d_{001}$ from Fig. 11 is plotted in Fig. 1(b)). It seems from Fig. 1(b) that $d_{001}=4.0 \mathrm{~nm}$ is also a step of crystalline swelling for $w_{\mathrm{f}}$ changes from $50.7 \%$ to

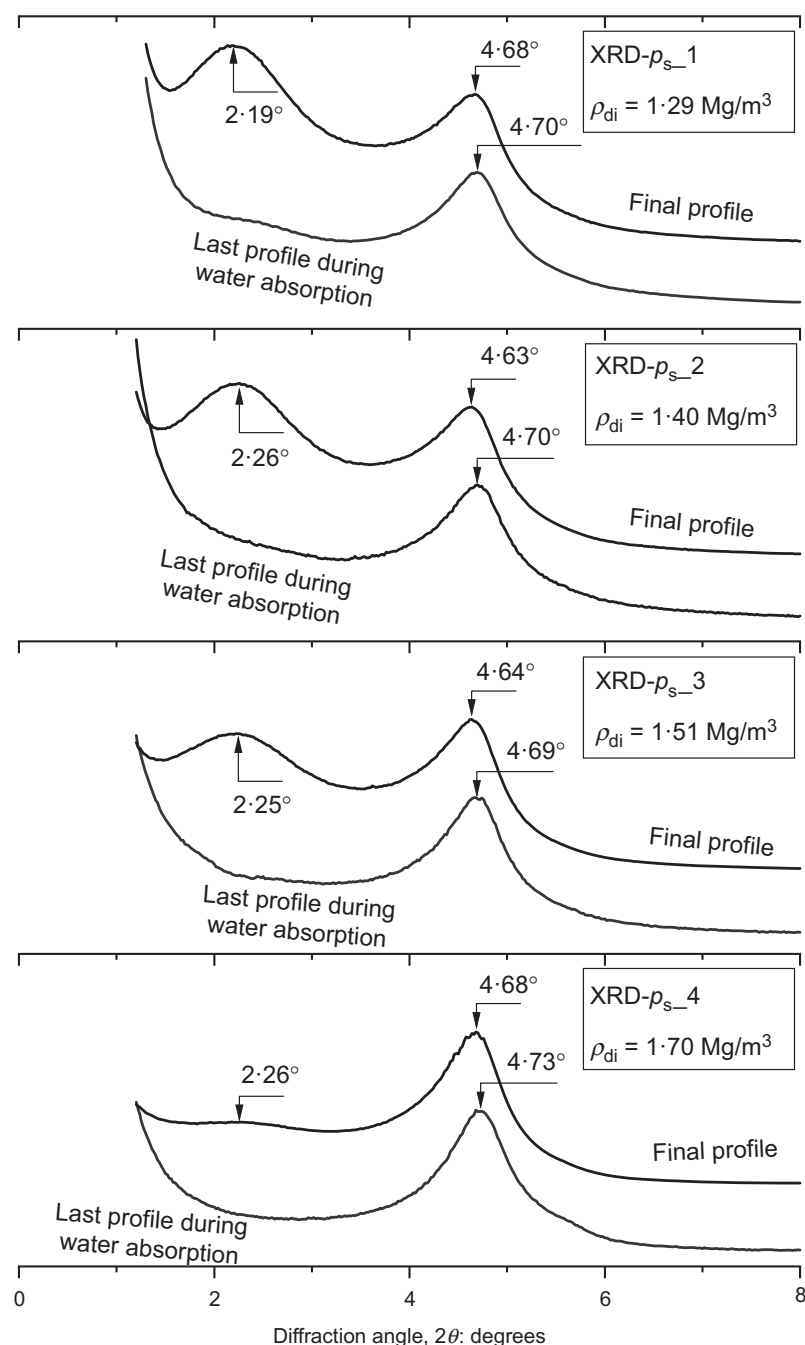

Fig. 11. Profiles before and after releasing swelling pressure

$32.5 \%$ (i.e. $d_{001}$ has no clear increase with an increasing $w$ ). Together with observations that peak intensity at $2 \theta_{\mathrm{pk}}=\sim 2 \cdot 2^{\circ}$ becomes weaker compared to that at $2 \theta_{\mathrm{pk}}=4 \cdot 7^{\circ}$ as $\rho_{\mathrm{di}}$ increases (Fig. 11), and the peak component at $2 \theta_{\mathrm{pk}}=\sim 2 \cdot 2^{\circ}$ may not be significant before the peak intensity reaches a maximum at $4.7^{\circ}$ (Fig. 9), even if swelling at $d_{001}=\sim 4.0 \mathrm{~nm}$ is osmotic swelling, one can infer that crystalline swelling might play a major role in the evolution of $p_{\mathrm{s}}$ for the conditions tested.

As possible extensional studies based on the findings in this study, it is also possible to distinguish the water contents of each hydration state in the interlayer space using the technique of XRD profile simulation (Cases et al., 1992; Ferrage et al., 2005; Warr \& Berger, 2007; Holmboe et al., 2012) or to predict the $p_{\mathrm{s}}$ curve by combining $d_{001}$ and interactions between swelling and non-swelling particles (Kyokawa et al., 2020).

\section{Results of swelling pressure tests}

Typical time histories of $p_{\mathrm{s}}$ are shown in Fig. 12, where $\rho_{\mathrm{df}}$ is presented above the curves. Feature points $\left(p_{\mathrm{p}}, p_{\mathrm{v}}\right.$ and $\left.p_{\mathrm{ei}}\right)$ are observed clearly in most cases, but $p_{\mathrm{p}}$ and $p_{\mathrm{v}}$ vanish as $\rho_{\mathrm{df}}$ becomes higher than $1.67 \mathrm{Mg} / \mathrm{m}^{3}$. For these $p_{\mathrm{s}}$ curves, the point with a minimum slope during the initial increase is used as $p_{\mathrm{p}}$ and the point with minimum curvature between $p_{\mathrm{p}}$ and $p_{\text {ei }}$ is used as $p_{\mathrm{v}}$. Interestingly, the time to reach $p_{\mathrm{p}}\left(t_{\mathrm{p}}\right)$ increases as $\rho_{\mathrm{df}}$ increases, whereas it is $1 \cdot 5-1 \cdot 7 \mathrm{~h}$ to reach $p_{\mathrm{v}}$ 
and $\sim 3 \mathrm{~h}$ to reach $p_{\mathrm{ei}}$ irrespective of $\rho_{\mathrm{df}}$, except for some specimens with very small $\rho_{\mathrm{df}}$. For specimens with $\rho_{\mathrm{df}}$ of less than $1.4 \mathrm{Mg} / \mathrm{m}^{3}, p_{\mathrm{s}}$ increases continuously after reaching $p_{\text {ei }}$,

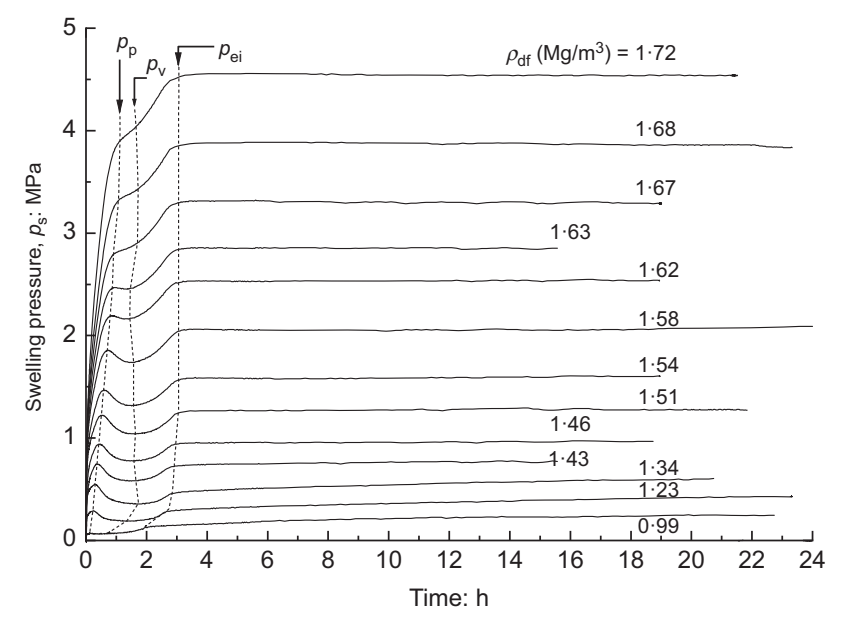

Fig. 12. Typical time histories of swelling pressure measurements which is not observed for denser specimens. Similar results are also observed from XRD- $p_{\mathrm{s}}$ tests in Fig. 9. Nevertheless, the last $p_{\mathrm{s}}$ measurement was assigned as $p_{\mathrm{eq}}$ for all tested specimens.

Figure 13 portrays the relation between $\rho_{\mathrm{df}}$ and $p_{\mathrm{p}}, t_{\mathrm{p}}$, $p_{\mathrm{v}}$ and $p_{\mathrm{ei}}$. The correlations are surprisingly good among all testing data and can be matched by an exponential equation. Similarly, Fig. 14 shows correlation between $\rho_{\mathrm{df}}$ and $p_{\text {eq }}$, which also suggests a good exponential relation. These relations in Figs 13 and 14 prove to be tools to predict values for feature points of $p_{\mathrm{s}}$ curves. Experimentally obtained results for K_V1 specimens with $\phi=28 \mathrm{~mm}$ and $t=10 \mathrm{~mm}$ in Wang et al. (2020c) and specimens with $\phi=60 \mathrm{~mm}$ and $t=20 \mathrm{~mm}$ in Tanaka \& Watanabe (2019) are also added to Fig. 14. These data are very close to results obtained from the present study. For data reported by Wang et al. (2020c), filter paper compression caused by specimen swelling deformation was not considered in the $\rho_{\mathrm{df}}$ calculations, which may have caused slightly smaller $\rho_{\mathrm{df}}$ values for the same $p_{\text {eq }}$. Because $p_{\text {eq }}$ increases exponentially with $\rho_{\text {df }}$, accurate estimation on $\rho_{\text {df }}$ becomes extremely important when estimating $p_{\text {eq }}$ for dense specimens. Additionally, as shown in Fig. 12, the time taken to reach $p_{\text {ei }}$ is about $3 \mathrm{~h}$ for most $t=2 \mathrm{~mm}$ specimens, which is significantly shorter than

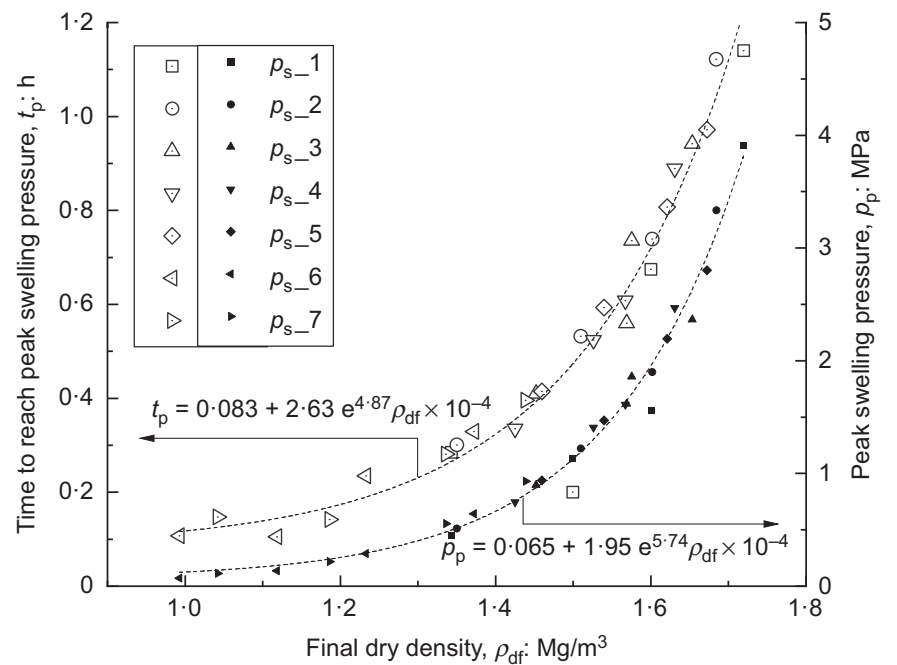

(a)

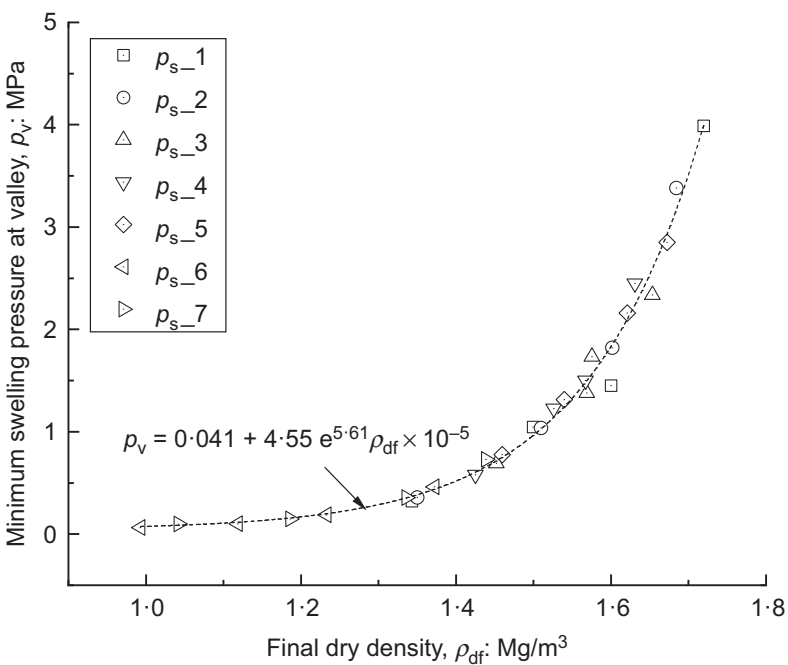

(b)

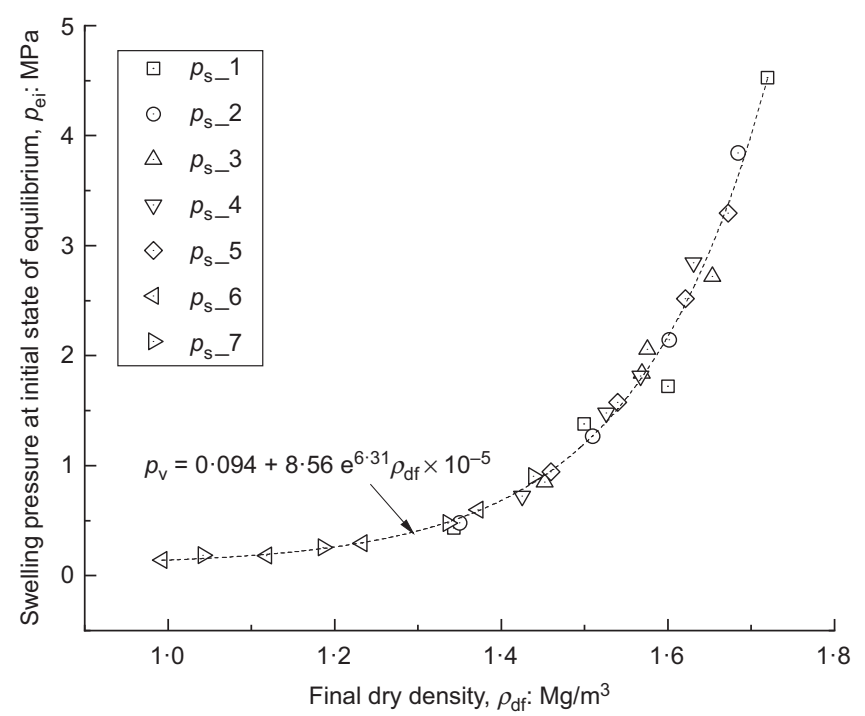

(c)

Fig. 13. Relations between $\rho_{\mathrm{df}}$ and: (a) $p_{\mathrm{p}}$ and $t_{\mathrm{p}}$; (b) $p_{\mathrm{v}}$; (c) $p_{\mathrm{ei}}$ 
the $\sim 3$ days for $t=10 \mathrm{~mm}$ specimens in Wang et al. (2020c) and the $\sim 15$ days for $t=20 \mathrm{~mm}$ specimens in Tanaka \& Watanabe (2019). Tests with $t=2 \mathrm{~mm}$ specimens were normally terminated within $24 \mathrm{~h}$, which is sufficiently short to conduct systematic studies to evaluate effects such as the type of bentonite, groundwater, temperature and so on on $p_{\mathrm{s}}$ behaviours. However, apparently, the particle size effect of target materials needs to be considered when employing this pressure cell. Finally, $\rho_{\mathrm{di}}$ and $p_{\mathrm{eq}}$ data measured in XRD- $p_{\mathrm{s}}$ tests are also shown in Fig. 12. Apparently, under the same $p_{\text {eq }}, \rho_{\text {di }}$ is much smaller than $\rho_{\mathrm{df}}$ of specimens in swelling pressure tests. The value $\rho_{\mathrm{df}}$ of four specimens in XRD- $p_{\mathrm{s}}$ tests is estimated using the exponential fitting equation (Table 1). This estimation implies that dry density $\left(\rho_{\mathrm{d}}\right)$ may decrease as much as $0.27 \mathrm{Mg} / \mathrm{m}^{3}$ during water absorption for a specimen with $\rho_{\mathrm{di}}=1.70 \mathrm{Mg} / \mathrm{m}^{3}$ in XRD- $p_{\mathrm{s}}$ tests. If this reduction was fully induced by the specimen thickness change, then $t$ of the specimen would increase by $\sim 0.3 \mathrm{~mm}$, which would seem to be too large. Another reason might be that swelling deformation is greater near the pressure sensor, resulting in density distribution variation.

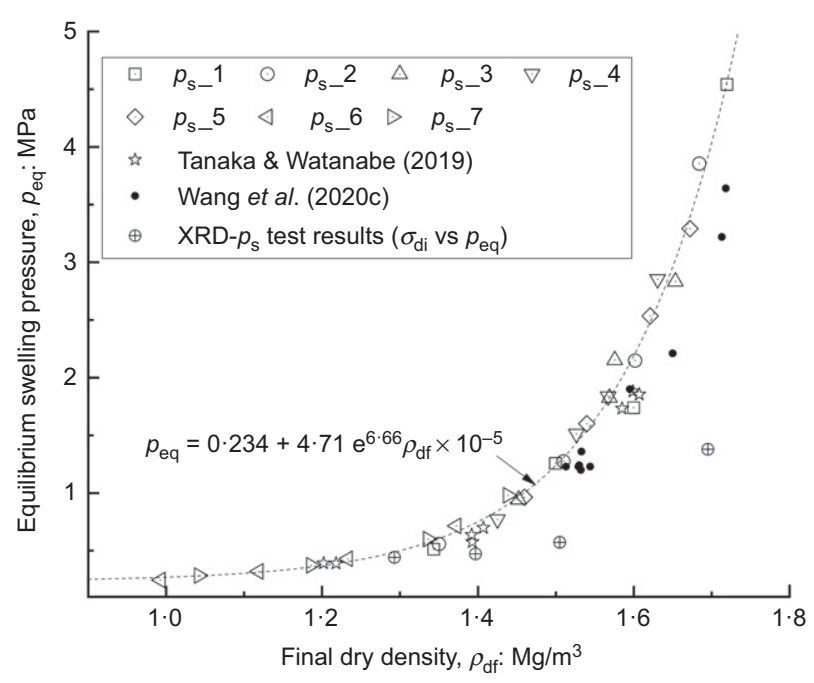

Fig. 14. Relation between $\rho_{\mathrm{df}}$ and $p_{\mathrm{eq}}$

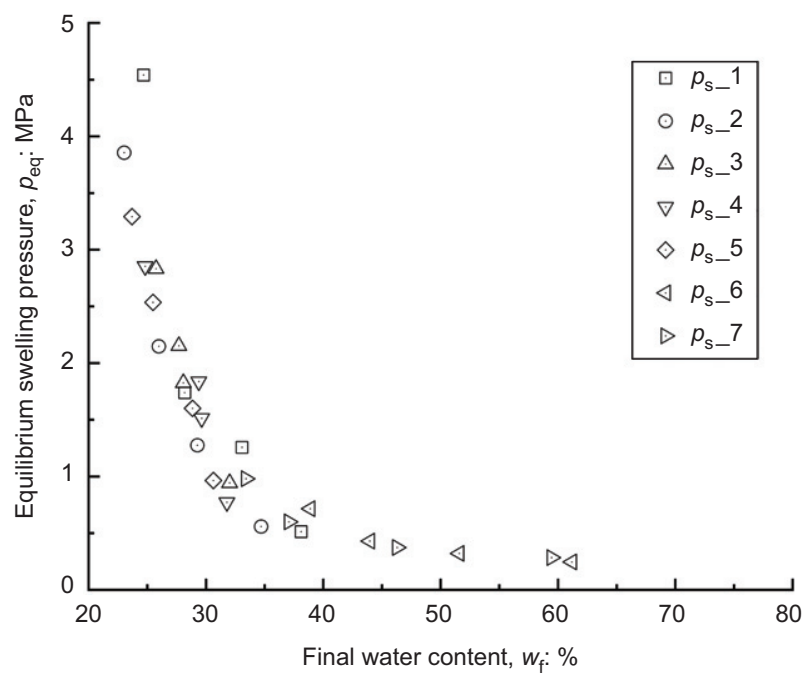

(a)
Correlation between $p_{\text {eq }}$ and $w_{\mathrm{f}}$ among all data, as shown in Fig. 15(a), also seems to be good, although the variation is slightly larger compared to the $\rho_{\mathrm{df}}$ and $p_{\text {eq }}$ relation. The calculated degree of saturation $\left(S_{\mathrm{r}}\right)$ of all specimens is shown to Fig. 15(b), which suggests that most of the specimens may not be fully saturated. This is possible, considering observations reported by Wang et al. (2020a) that the $w$ vertical distribution after water supply for 19 days for a $t=10 \mathrm{~mm}$ specimen was not uniform (i.e. higher $w$ for the part close to water supply end, and vice versa), although $p_{\text {eq }}$ was achieved in 7 days. Unsaturated conditions are expected to be a reason for worse correlation between $p_{\text {eq }}$ and $w_{\mathrm{f}}$ than that between $p_{\text {eq }}$ and $\rho_{\text {df. The value }} S_{\mathrm{r}}$ of some specimens exceeds $100 \%$, which was often interpreted by the possibility of higher water density $\left(\rho_{\mathrm{w}}\right)$ than $1 \mathrm{Mg} / \mathrm{m}^{3}$ for water in the interlayer space of montmorillonite (Pusch et al., 1990; Villar \& Lloret, 2004; Jacinto et al., 2012). Herein, another possibility is given: the experimental measurement variation. $S_{\mathrm{r}}$ can be expressed as

$$
S_{\mathrm{r}}=\frac{w G_{\mathrm{s}} \rho_{\mathrm{d}}}{G_{\mathrm{s}} \rho_{\mathrm{w}}-\rho_{\mathrm{d}}}
$$

By taking a partial derivative, the following is obtained

$$
\partial S_{\mathrm{r}}=\frac{G_{\mathrm{s}} \rho_{\mathrm{d}}}{G_{\mathrm{s}} \rho_{\mathrm{w}}-\rho_{\mathrm{d}}} \partial w+\frac{G_{\mathrm{s}}^{2} w \rho_{\mathrm{w}}}{\left(G_{\mathrm{s}} \rho_{\mathrm{w}}-\rho_{\mathrm{d}}\right)^{2}} \partial \rho_{\mathrm{d}}-\frac{\rho_{\mathrm{d}}^{2} w}{\left(G_{\mathrm{s}} \rho_{\mathrm{w}}-\rho_{\mathrm{d}}\right)^{2}} \partial G_{\mathrm{s}}
$$

By setting $G_{\mathrm{s}}=2 \cdot 8, \rho_{\mathrm{w}}=1 \mathrm{Mg} / \mathrm{m}^{3}$ and the true value of $S_{\mathrm{r}}=100 \%$, the upper boundary lines for calculated $S_{\mathrm{r}}$ for different $\partial w, \partial \rho_{\mathrm{d}}$ and $\partial G_{\mathrm{s}}$ are shown in Fig. 15(b). Also, $\partial G_{\mathrm{s}}$ and $\partial w$ are set as respectively referring to Figs 2 and 5. For the present study, possible specimen swelling deformation was considered for the $\rho_{\mathrm{df}}$ calculation, while it was also found that membrane filter compression and pressure cell expansion were not very uniform, and that $\partial \rho_{\mathrm{d}}=$ up to $0.02 \mathrm{Mg} / \mathrm{m}^{3}$ would be possible. As shown in Fig. 15(b), $S_{\mathrm{r}}>100 \%$ is also possible, even for $\rho_{\mathrm{w}}=1 \mathrm{Mg} / \mathrm{m}^{3}$.

\section{CONCLUSION}

A swelling pressure cell was developed to measure apparent swelling pressure $\left(p_{\mathrm{s}}\right)$ as well as basal spacing of montmorillonite $\left(d_{001}\right)$ simultaneously when compacted

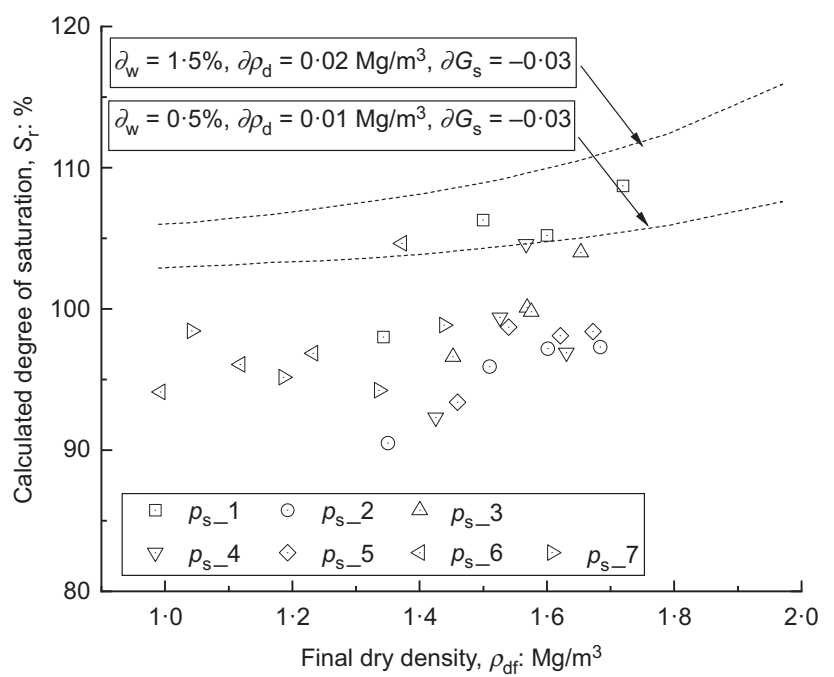

(b)

Fig. 15. (a) Relation between $w_{\mathrm{f}}$ and $p_{\text {eq }}$; (b) relation between $\rho_{\mathrm{df}}$ and calculated $S_{\mathrm{r}}$ 
bentonite is wetted by distilled water. Test results show that this pressure cell can capture features of the $p_{\mathrm{s}}$ time history curve and $d_{001}$ well. Some technical difficulties remain, however, such as swelling deformation reduction of the dry density of tested specimens, and diffraction peak position changes induced by materials employed as X-ray windows (beryllium plate and polyester film). XRD measurements of initially oven-dried bentonite specimens show that $d_{001}$ moves from $0.98 \mathrm{~nm}$ to $1.26 \mathrm{~nm}, 1.58 \mathrm{~nm}, 1.90 \mathrm{~nm}$ and to $\sim 4.0 \mathrm{~nm}$ gradually as $p_{\mathrm{s}}$ experiences a sharp increase to the peak swelling pressure $\left(p_{\mathrm{p}}\right)$, then a drop to a valley swelling pressure $\left(p_{\mathrm{v}}\right)$ and another increase to the initial swelling pressure for equilibrium $\left(p_{\mathrm{ei}}\right)$, and finally with $p_{\mathrm{s}}$ reaching the equilibrium $\left(p_{\text {eq }}\right)$. From these observations, it is concluded that crystalline swell of montmorillonite serves an important role in interpreting the $p_{\mathrm{s}}$ time history for tested specimens. The swelling pressure cell is also used to measure the $p_{\mathrm{s}}$ time history of compacted bentonite specimens that are $2 \mathrm{~mm}$ thick. Results suggest that the specimen dry density has a surprisingly good correlation with the feature points of the $p_{\mathrm{s}}$ time history (i.e. $p_{\mathrm{p}}, p_{\mathrm{v}}, p_{\mathrm{ei}}$ and $p_{\mathrm{eq}}$ ), which provides a tool of feature point prediction. The test duration of the $2 \mathrm{~mm}$ specimen is less than $24 \mathrm{~h}$, which is significantly shorter than those of past studies. Results show that the degree of saturation may exceed $100 \%$ of some bentonite specimens after water absorption, for which it can be pointed out that the reason for this might be higher water density in the interlayer space of montmorillonite, while variation in measurements is expected to be another possible source.

\section{ACKNOWLEDGEMENTS}

Some of this work was performed as a part of the activities of the Research Institute of Sustainable Future Society, Waseda Research Institute for Science and Engineering, Waseda University. Part of this study was supported by the Ministry of Economy, Trade and Industry (METI) of Japan and Waseda University Grant for Special Research Projects (project numbers: 2020C-647 and 2020C-039). Mr Takashi Yoshida and group members of the manufacturing laboratory of Waseda University, Kyowa Electronic Instruments Co., Ltd, Pascal Co. Ltd and Pall Corp. provided important technical support during apparatus development. All XRD tests were conducted and technically supported by the materials characterisation central laboratory, Waseda University (Izutani et al., 2016). Mr Kunlin Ruan provided valuable review comments. The authors express their deep gratitude to all those mentioned above.

\section{NOTATION}

$0 \mathrm{w}, 1 \mathrm{w}, 2 \mathrm{w}, 3 \mathrm{w}$ no layer, one layer, two layers or three layers of water molecules in the interlayer space of montmorillonite, respectively

$d_{001}$ basal spacing of montmorillonite

$G_{\mathrm{s}} \quad$ specific gravity

$L$ layers of water molecules in the interlayer space of montmorillonite

$M \quad$ specimen mass

$p_{\mathrm{ei}} \quad$ initial swelling pressure for equilibrium on $p_{\mathrm{s}}$ time history

$p_{\text {eq }} \quad$ equilibrium swelling pressure on $p_{\mathrm{s}}$ time history

$p_{\mathrm{p}}$ peak swelling pressure on $p_{\mathrm{s}}$ time history

$p_{\mathrm{s}}$ apparent swelling pressure of compacted bentonite during wetting

$p_{\mathrm{v}} \quad$ valley swelling pressure on $p_{\mathrm{s}}$ time history

$S_{\mathrm{r}}$ degree of saturation

$t$ thickness $t_{\mathrm{p}} \quad$ corresponding water absorption time for $p_{\mathrm{s}}$ to reach $p_{\mathrm{p}}$

$V \quad$ inner volume of the specimen ring

$w$ water content

$w_{\mathrm{f}}$ final water content

$w_{\mathrm{i}}$ initial water content

$\theta$ half of the angle between the incident and diffracted X-ray beams of the diffractometer

$\theta_{\mathrm{pk}}$ diffraction angle of a mineral, which equals $\theta$ at the peak position of the $\mathrm{X}$-ray scanned profile

$\lambda$ wavelength of incident $\mathrm{X}$-ray beams $(=0 \cdot 15418 \mathrm{~nm}$ for $\mathrm{Cu} \mathrm{K} \alpha$ source)

$\rho_{\mathrm{d}}$ dry density

$\rho_{\mathrm{df}} \quad$ final dry density

$\rho_{\mathrm{di}} \quad$ initial dry density

$\rho_{\mathrm{w}} \quad$ water density

$\phi$ diameter

\section{REFERENCES}

Afzal, S., Tesler, W. J., Blessing, S. K., Collins, J. M. \& Lis, L. J. (1984). Hydration force between phosphatidylcholine surfaces in aqueous electrolyte solutions. J. Colloid Interface Sci. 97, No. 2, 303-307, https://doi.org/10.1016/0021-9797(84)90300-X.

Anderson, R. L., Ratcliffe, I., Greenwell, H. C., Williams, P. A., Cliffe, S. \& Coveney, P. V. (2010). Clay swelling - a challenge in the oilfield. Earth-Sci. Rev. 98, No. 3-4, 201-216, https://doi. org/10.1016/j.earscirev.2009.11.003.

Cases, J. M., Berend, I., Besson, G., Francois, M., Uriot, J. P., Thomas, F. \& Poirier, J. E. (1992). Mechanism of adsorption and desorption of water vapor by homoionic montmorillonite. 1 . The sodium-exchanged form. Langmuir 8, No. 11, 2730-2739, https://doi.org/10.1021/la00047a025.

Dinnebier, R. E. \& Billinge, S. J. L. (2008). Power diffraction theory and practice. Cambridge, UK: RSC Publishing.

Ferrage, E., Lanson, B., Sakharov, B. A. \& Drits, V. (2005). Investigation of smectite hydration properties by modeling experimental X-ray diffraction patterns: part I. Montmorillonite hydration properties. Am. Mineral. 90, No. 8-9, 1358-1374, https://doi.org/10.2138/am.2005.1776.

Fink, D. H. \& Thomas, G. W. (1964). X-ray studies of crystalline swelling in montmorillonites. Soil Sci. Soc. Am. Proc. 28, No. 6, 747-750, https://doi.org/10.2136/sssaj1964. $03615995002800060021 x$.

Fink, D. H., Rich, C. I. \& Thomas, G. W. (1968). Determination of internal surface area, external water, and amount of montmorillonite in clay-water systems. Soil Sci. 105, No. 2, 71-77.

Foster, W. R., Savins, J. G. \& Waite, J. M. (1954). Lattice expansion and rheological behavior relationships in watermontmorillonite systems. Clays Clay Miner. 3, No. 1, 296-316, https://doi.org/10.1346/CCMN.1954.0030124.

Harada, J. (2003). X-ray source and X-ray optics based on multilayer. J. Cryst. Soc. Jpn 45, No. 5, 306-313, https://doi.org/ $10.5940 /$ jcrsj.45.306.

Holmboe, M., Wold, S. \& Jonsson, M. (2012). Porosity investigation of compacted bentonite using XRD profile modeling. J. Contam. Hydrol. 128, No. 1-4, 19-32, https://doi.org/10.1016/ j.jconhyd.2011.10.005.

Israelachvili, J. N. (2011). Intermolecular and surface forces, $3 \mathrm{rd} \mathrm{edn.}$ Burlington, MA, USA: Elsevier.

Iwasaki, T. \& Watanabe, T. (1988). Distribution of Ca and $\mathrm{Na}$ ions in dioctahedral smectites and interstratified dioctahedral mica/smectites. Clays Clay Miner. 36, No. 1, 73-82, https://doi.org/10.1346/CCMN.1988.0360110.

Izutani, C., Fukagawa, D., Miyashita, M., Ito, M., Sugimura, N., Aoyama, R., Gotoh, T., Shibue, T., Igarashi, Y. \& Oshio, H. (2016). The materials characterization central laboratory: an open-end laboratory program for fourth-year undergraduate and graduate students. J. Chem. Educ. 93, No. 9, 1667-1670, https://doi.org/10.1021/acs.jchemed.6b00161.

Jacinto, A. C., Villar, M. V. \& Ledesma, A. (2012). Influence of water density on the water-retention curve of expansive clays. Géotechnique 62, No. 8, 657-667, https://doi.org/10.1680/ geot.7.00127. 
JGS (Japanese Geotechnical Society) (2009). JGS 0111-2009: Test method for density of soil particles. Tokyo, Japan: Japanese Geotechnical Society.

JNC (Japan Nuclear Cycle) (1999). JNC TN1400 99-020: Technical reliability of the geological disposal for high-level radioactive waste in Japan - geological disposal research and development. Second compiled - general report. Tōkai, Japan: Japan Nuclear Cycle Development Institute (in Japanese). See https://www. jaea.go.jp/04/tisou/houkokusyo/dai2jitoimatome.html (accessed $10 / 02 / 2019)$.

Komine, H. (2004). Simplified evaluation for swelling characteristics of bentonites. Engng Geol. 71, No. 3-4, 265-279, https://doi.org/ 10.1016/S0013-7952(03)00140-6.

Kyokawa, H., Ohno, S. \& Kobayashi, I. (2020). A method for extending a general constitutive model to consider the electro-chemo-mechanical phenomena of mineral crystals in expansive soils. Int. J. Numer. Analyt. Methods 44, No. 6, 749-771, https://doi.org/10.1002/nag.3026.

Lubetkin, S. D., Middleton, S. R. \& Ottewill, F. R. S. (1984). Some properties of clay-water dispersions. Phil. Trans. R. Soc. A 311, No. 1517, 353-368, https://doi.org/10.1098/rsbm.2010.0017.

Meleshyn, A. \& Bunnenberg, C. (2005). The gap between crystalline and osmotic swelling of Na-montmorillonite: a Monte Carlo study. J. Chem. Phys. 122, No. 3, 034705, https://doi.org/ $10.1063 / 1.1834499$.

METI (Ministry of Economy, Trade and Industry) (2018). Learn from foreign experience in HLW management - 2018 version. Tokyo, Japan: Agency for Natural Resources and Energy, Ministry of Economy, Trade and Industry (in Japanese), http:// www2.rwmc.or.jp/publications:hlwkj2018 (accessed 10/02/2019).

Moore, D. M. \& Hower, J. (1986). Ordered interstratification of dehydrated and hydrated Na-smectite. Clays Clay Miner. 34, No. 4, 379-384.

Moore, D. M. \& Reynolds, R. C. (1997). X-ray diffraction and the identification and analysis of clay minerals, 2nd edn. New York, NY, USA: Oxford University Press.

Morodome, S. \& Kawamura, K. (2009). Swelling behavior of Naand Ca-montmorillonite up to 150 by in situ X-ray diffraction experiments. Clays Clay Miner. 57, No. 2, 150-160. https://doi. org/10.1346/CCMN.2009.0570202.

Norrish, K. (1954). Crystalline swelling of montmorillonite: manner of swelling of montmorillonite. Nature 173, No. 4397, 256-257, https://doi.org/10.1038/173256a0.

Olis, A. C., Malla, P. B. \& Douglas, L. A. (1990). The rapid estimation of the layer charges of 2:1 expanding clays from a single alkylammonium ion expansion. Clay Miner. 25, No. 1, 39-50, https://doi.org/10.1180/claymin.1990.025.1.05.

Posiva (2012). Safety case for the disposal of spent nuclear fuel at Olkiluoto - Synthesis 2012. Eurajoki, Finland: Posiva Oy.

Pusch, R. (1980). Swelling pressure of highly compacted bentonite, KBS Technical Report, KBS Proj. 15:05. Luelå, Sweden: University of Luleå.

Pusch, R., Karnland, O. \& Hökmark, H. (1990). GMM-A general microstructural model for qualitative and quantitative studies of smectite clays, SKB Technical Report 90-43. Stockholm, Sweden: Svensk Kärnbränslehantering AB.

Ravina, I. \& Low, P. F. (1972). Relation between swelling, water properties and $b$-dimension in montmorillonite-water systems. Clays Clay Miner. 20, No. 3, 109-123, https://doi.org/10.1346/ CCMN.1972.0200302.

Ravina, I. \& Low, P. F. (1977). Change of $b$-dimension with swelling of montmorillonite. Clays Clay Miner. 25, No. 3, 201-204, https://doi.org/10.1346/CCMN.1977.0250305.

Sato, T., Watanabe, T. \& Otsuka, R. (1992). Effects of layer charge, charge location, and energy change on expansion properties of dioctahedral smectites. Clays Clay Miner. 40, No. 1, 103-113, https://doi.org/10.1346/CCMN.1992.0400111.

SKB (Svensk Kärnbränslehantering AB) (2011). Long-term safety for the final repository for spent nuclear fuel at Forsmark - main report of the SR-site project. Stockholm, Sweden: Svensk Kärnbränslehantering $\mathrm{AB}$.

Sridharan, A., Rao, A. \& Sivapullaiah, P. (1986). Swelling pressure of clays. Geotech. Test. J. 9, No. 1, 24-33.
Sun, D. A., Zhang, J. Y., Zhang, J. R. \& Zhang, L. (2013). Swelling characteristics of GMZ bentonite and its mixtures with sand. Appl. Clay Sci. 83-84, 224-230, https://doi.org/10.1016/j.clay. 2013.08.042.

Takahashi, Y., Kawamura, K., Sato, T., Kobayashi, I. \& Ichikawa, Y. (2015). In situ X-ray diffraction observation of smectite hydration under constant volume. J. Nucl. Sci. Technol. 52, No. 12, 1470-1479, https://doi.org/10.1080/00223131.2015. 1009955.

Tanai, K., Kikuchi, H., Nakamura, K., Tanaka, Y. \& Hironaga, M. (2010). Survey on current status of laboratory test method and experimental consideration for establishing standardized procedure of material containing bentonite, Report of collaboration research between JAEA and CRIEPI, JAEA-Research 2010-025. Tōkai, Japan: Japan Atomic Energy Agency (in Japanese).

Tanaka, Y. \& Watanabe, Y. (2019). Modelling the effects of test conditions on the measured swelling pressure of compacted bentonite. Soils Found. 59, No. 1, 136-150, https://doi.org/ 10.1016/j.sandf.2018.09.009.

Viani, B. E., Low, P. F. \& Roth, C. B. (1983). Direct measurement of the relation between interlayer force and interlayer distance in the swelling of montmorillonite. J. Colloid Interface Sci. 96, No. 1, 229-244, https://doi.org/10.1016/0021-9797(83)90025-5.

Villar, M. V. \& Lloret, A. (2004). Influence of temperature on the hydro-mechanical behaviour of a compacted bentonite. Appl. Clay Sci. 26, No. 1-4, 337-350, https://doi.org/10.1016/j.clay. 2003.12.026.

Villar, M. V. \& Lloret, A. (2008). Influence of dry density and water content on the swelling of a compacted bentonite. Appl. Clay Sci. 39, No. 1-2, 38-49, https://doi.org/10.1016/j.clay.2007.04. 007.

Wang, Q., Tang, A. M., Cui, Y. J., Delage, P. \& Gatmiri, B. (2012). Experimental study on the swelling behaviour of bentonite/claystone mixture. Engng Geol. 124, 59-66, https://doi.org/10.1016/j.enggeo.2011.10.003.

Wang, H., Koseki, J., Nishimura, T. \& Miyashita, Y. (2017). Membrane filter properties and application of the filter to undrained cyclic triaxial test of unsaturated materials. Can. Geotech. J. 54, No. 8, 1196-1202, https://doi.org/10.1139/ cgj-2016-0507.

Wang, H., Shirakawabe, T., Komine, H., Ito, D., Gotoh, T., Ichikawa, Y. \& Chen, Q. (2020a). Movement of water in compacted bentonite and its relation with swelling pressure. Can. Geotech. J. 57, No. 6, 921-932, https://doi.org/10.1139/ cgj-2019-0219.

Wang, H., Shibue, T. \& Komine, H. (2020b). Hydration and dehydration of water of bentonite: a solid-state $1 \mathrm{H}$ magic-angle spinning NMR study. Chem. Phys. 536, 110796, https://doi.org/ 10.1016/j.chemphys.2020.110796.

Wang, H., Komine, H. \& Shirakawabe, T. (2020c). Development of an apparatus for swelling pressure of compacted bentonite. In Proceedings of the 55th Japan national conference on geotechnical engineering, paper 21-5-5-01. Tokyo, Japan: Japanese Geotechnical Society (in Japanese).

Warkentin, B. P. (1962). Water retention and swelling pressure of clay soils. Can. J. Soil Sci. 42, No. 1, 189-196, https://doi.org/10. 4141/cjss62-024.

Warr, L. \& Berger, J. (2007). Hydration of bentonite in natural waters: application of 'confined volume' wet-cell X-ray diffractometry. Phys. Chem. Earth 32, No. 1-7, 247-258, https://doi.org/10.1016/j.pce.2006.02.048.

Watanabe, T. \& Sato, T. (1988). Expansion characteristics of montmorillonite and saponite under various relative humidity conditions. Clay Sci. 7, No. 3, 129-138, https://doi.org/ 10.11362/jcssjclayscience1960.7.129.

Yamada, H., Nakazawa, H., Hashizume, H. \& Shimomura, S. (1994). Hydration behavior of Na-smectite crystals synthesized at high pressure and high temperature. Clays Clay Miner. 42, No. 1, 77-80, https://doi.org/10.1346/CCMN.1994.0420110.

Zhang, Z. Z. \& Low, P. F. (1989). Relation between the heat of immersion and the initial water content of $\mathrm{Li}-, \mathrm{Na}-$, and K-montmorillonite. J. Colloid Interf. Sci. 133, No. 2, 461-472, https://doi.org/10.1016/S0021-9797(89)80057-8. 